\title{
Assessment of by-products of Bioenergy systems (Anaerobic Digestion and Gasification) as potential crop nutrient
}

SAMPRITI KATAKI ${ }^{\mathrm{a}}$, SAMARENDRA HAZARIKA ${ }^{\mathrm{b}}$, DC BARUAH $^{\mathrm{a}^{*}}$

\begin{abstract}
Alternative fertilizer resources have drawn attention in recent times in order to cope up with ever increasing demand for fertilizer. By-products of bioenergy system are considered favourable as organic fertilizer due to their ability to recycle plant nutrients. Present study evaluates fertilizer suitability of by-products of two bioenergy systems viz. 3 types of anaerobic digestion by-products (digestate) from local surplus biomass such as cowdung, Ipomoea carnea:cowdung (60:40) and ricestraw: green gram stover:cowdung (30:30:40) and one gasification by-product (biochar) from rice husk. Digestates were assessed considering 4 different application options of each viz. whole, solid, liquid and ash from solid digestates. Digestate characteristics (organic matter, macronutrients, micronutrients and heavy metal content) were found to be a function of feedstock and processing (solid liquid separation and ashing). Ipomoea carnea based digestates in all application options showed comparatively higher $\mathrm{N}, \mathrm{P}, \mathrm{K}, \mathrm{NH}_{4}{ }^{+}-\mathrm{N}, \mathrm{Ca}, \mathrm{Mg}, \mathrm{S}$ and micro nutrient content than other digestates. Separation concentrated plant nutrients and organic matter in solid digestates, making these suitable both as organic amendments and fertilizer. Separated liquid digestate shared larger fraction of ammonium nitrogen (61-91\% of total content), indicating their suitability as readily available $\mathrm{N}$ source. However, fertilizer
\end{abstract}


1 application of liquid digestate may not match crop requirements due to lower total nutrient

2 concentration. Higher electrical conductivity of the liquid digestates $\left(3.4-9.3 \mathrm{mS} \mathrm{cm} \mathrm{cm}^{-1}\right)$ than

3 solid digestates $\left(1.5-2 \mathrm{mS} \mathrm{cm}^{-1}\right)$ may impart phyto -toxic effect upon fertilization due to

4 salinity. In case of by-products with unstable organic fraction i.e whole and solid digestates

5 of rice straw:green gram stover:cowdung digestates (Humification index 0.7), further

6 processing (stabilization, composting) may be required to maximize their fertilizer benefit.

7 Heavy metal contents of the by-products were found to be within the permitted range

8 specified for organic fertilizer (vermicompost) in India. However, higher Al content of the

9 digestates in whole, solid and ash phase (0.06-16.97 $\mathrm{g} \mathrm{kg}^{-1}$ fresh matter) can be a concern in 10 acid soil which may cause Al toxicity.

11 Understanding on agrochemical characteristics of bioenergy by -products with varying feedstock and application option is expected to promote their valorization opportunities considering user specific requirements. In the context of agriculturally dominant but energy deficient rural Indian scenario, integrated production of bioenergy and by-product based fertilizer could be very significant to meet the critical additional requirement of both energy and fertilizer. Keywords: Anaerobic digestion, Gasification, Bioenergy, By-products, Fertilizer, Nutrients

\section{Introduction}

Intensification of agricultural sector is imperative to ensure food security for growing population which is projected to reach 9.7 billion by 2050 (UN, 2015). To meet the associated global food demand, a necessary rise of $60 \%$ in current agricultural production by 2050 has been estimated by Food and Agriculture Organization of United Nations (FAO, 2013). For achieving such agricultural intensification, supplementation of external nutrient input to replenish soil is vitally important which is is primarily done through chemical fertilizer. However, the prospect of organic fertilizer for enhancing crop production and 
1 sustaining soil health has also been realized. In this context, by-products of bioenergy

2 systems could also be considered as prospective organic fertilizers, as it retains nutrients from input raw materials (Salminen et al., 2001; Gell et al. 2011). Furthermore, unpredictable cost dynamics and harmful impact of prolonged use linked with chemical fertilizer have also led to consideration of recycling of these organic residues to land as a practice of nutrient conservation and management.

Bioenergy by-products (BEBPs) such as (i) digestate from anaerobic digestion (AD) that produces biogas and (ii) biochar from biomass gasification (BG) that produces producer gas are inevitable commodities of bioenergy conversion process (Taheripour et al., 2010; Galvez et al., 2012). Consideration and management of these residues along with main energy output are essentially required for comprehensive assessment and sustainability of bioenergy system (Taheripour et al., 2010; Wang, 2011; Galvez, 2012, Dahlin et al., 2015). With faster expansion of anaerobic digestion and gasification technologies empowering rural areas of developing countries, it is expected that, there will also be simultaneous increase in the by-products generated. Depending upon the feedstock, about 5-80\% of input feedstock is generated as residue in energy conversion process (Moller et al., 2012). Thus, major portion of residue remains to be handled in bioenergy production process, calling for their proper management.

$\mathrm{AD}$ and $\mathrm{BG}$ processes have high adaptation to undertake a range of feedstock, which led to generation of by-products with varying physico-chemical characteristics (Abubaker et al., 2012, Enders et al., 2012). The fertilizer potentials of digestates from poultry slaughterhouse waste (Salminen et al., 2001), municipal sludge (Tambone et al., 2010; Massaccesi et al., 2013), cowdung, human excreta, pig slurry (Gell et al., 2011), guinea pig manure (Garfi et al., 2011), farm and agro industrial residue (Alburquerque et al., 2012), cow dung and chicken droppings (Alfa et al., 2014), Maize silage (Nabel et al., 2014; Westphal et 
1 al., 2016), food waste co-digested with human excreta (Owamah et al., 2014); food waste

2 (Chiew et al., 2015, Tampio et al., 2016), sugar beet pulp, fruit marc, maize silage (García-

3 Sanchez et al., 2015) were shown to be a function of feedstock. These studies discussed

4 various chemical and biological (macro and micro nutrient, heavy metal, organic content, $\mathrm{pH}$,

5 cation exchange capacity, chemical and biochemical oxygen demand, electrical conductivity,

6 microbial mass, pathogenic content, phyto-toxicty) and physical indicators (dry matter,

7 suspended solid, odour, dissolved solid) to evaluate quality of digestate as fertilizer. In general,digestates are reported to contain nutrients with enhanced bio-availability $(60-80 \%$ of total nitrogen in mineralized form along with bioavailable phosphorus and potassium), making these a suitable consideration as soil applicant (Tambone et al., 2009; Garfi et al., 2011; Makadi et al., 2012).

Performance of digestates as soil applicant is found to be encouraging depending upon quality and nutritional status (Arthurson, 2009). Benefits of digestate application are reported as enhanced crop yield (Rivard et al., 1995; Kocar, 2008; Vaneeckhaute et al., 2013), plant nutrient uptake (Rubaeket al., 1996; de Boer, 2008; Terhoeven-Urselmans et al., 2009; Bachmann et al., 2011; Andruschkewitsch et al., 2013, Koszel and Lorencowicz et al., 2015) and enhanced soil quality through higher available $\mathrm{N}$ and $\mathrm{P}$, nitrogen mineralization capacity, soil respiration, increased microbial activity and diversity (Friedel et al., 1996; Odlare et al., 2008; Galvez et al., 2012; Sapp et al., 2015; García-Sanchez et al., 2015). Performance of digestate was reported to be at par with chemical fertilizer in terms of crop yield and soil properties by some other researchers (Adelekan et al., 2010; Loria et al., 2007; Chantigny et al. 2008; Abubaker et al., 2012; Herrmann et al., 2013; Riva et al., 2016). As seen from the above discussion, though the fertilizer value of digestate could be realized, however, there are some feedstock related and managerial issues that can limit their 
1 due to increased soil salinity, soil heavy metal accumulation, introduction of contaminant,

2 phyto toxicity, ecotoxicity that may arise from feedstock dependent digestate properties

3 (WRAP, 2009; Govasmark et al., 2011; Massaccesi et al., 2013; Islam et al., 2014; Kupper et

4 al., 2014; Chiew et al., 2015; Tigini et al., 2016). There are also some managerial issues such

5 as problems of bulk handling, transportation that increase distribution cost (Horan, 2012),

6 nutrient leaching and pollution from emission $\left(\mathrm{N}_{2} \mathrm{O}, \mathrm{CH}_{4}\right)$ due to improper method of

7 application and storage (Sharpley and Moyer, 2000; Eickenscheidt et al., 2014; Zeshan and

8 Visvanathan, 2014; Riva et al., 2016), resulting in non-optimized utilization of digestate. To

9 address these issues, some processing methods such as dewatering, solid liquid separation and stabilization (composting) have been proposed to obtain products suitable for different uses (Balsari and Menardo 2009; Teglia et al., 2011). However, understanding on characterization and distribution of nutrients with respect to varied feedstock and processing are required for appropriate and selective use.

Similarly, application of biochar, a by-product of gasification was reported to increased crop productivity, soil organic carbon, total N, extractable $\mathrm{P}, \mathrm{K}, \mathrm{Mg}$ (Laird et al., 2010; Zhang et al., 2012; Gelvez et. al., 2012). Potential benefits of biochar as fertilizer are generally attributed to its capacity to enhance soil property through carbon sequestration and reduced GHG emission (Lehmann et al., 2006). Fertilizing effect of biochar depends upon input feedstock and method of application (Gell et al., 2011). To summarize the above discussion, benefits of BEBP as crop nutrient have been almost conclusively evidenced from the previous works. The prospect of application of such alternative fertilizer resource is very significant in Indian context, as the critical additional requirement of both energy and fertilizer could be understood from Table 1. Particularly in North East India, where per capita energy availability (1221 MU) is lower than the national average (96739 MU) and also chemical fertilizer input $\left(66 \mathrm{~kg} \mathrm{ha}^{-1}\right)$ in agriculture is far lower 
1 than the national average $\left(128 \mathrm{~kg} \mathrm{ha}^{-1}\right)$ (Table 1$)$, integrated production of bioenergy and by-

2 product based fertilizer production are expected to ensure sufficient nutrients inputs for crop

3 production and for promotion of energy. However, there are certain region specific research

4 issues to be addressed in the area of by-product utilization to adequately upgrade these to a

5 general acceptable level or to make it competent with the chemical fertilizer.

$6 \quad$ Keeping in view of the above discussion, this work is undertaken to generate required

7 knowhow to promote BEBPs into value added commodity. A comprehensive characterization

8 of the BEBP with all possible options of its application would help to evaluate its fertilizer

9 value. Understandings on the nutritional characteristics of the BEBPs as fertilizer with

10 variation of feedstock and application option (whole digestate /separated solid digestate

11 /separated liquid digestate /ash from solid digestate and char) are important aspects of research which are investigated in the present study.

\section{Table 1 Energy, Power and Fertilizer scenario in India}

\section{Materials \& Methods}

Present study considers by-products of two bio-energy systems viz. (i) 3 types of anaerobic digestates from biogas reactor and (ii) 1 type of biochar from gasification reactor. Further, 4 application options were considered for each digestate viz. whole, solid, liquid and ash phase. Table 2 presents the description of the selected BEBPs (total 13), whereas, steps used for preparation and processing of the BEBPs are presented in Fig. 1.

\section{Table 2 Details of bioenergy by-products}

\subsection{Description of feedstock}

Three different types of feedstock are considered for anaerobic digestion i.e. (i) cowdung (ii) Ipomoea carnea leaves codigested with cowdung (60:40 dry weight basis) and

(iii) rice straw and green gram stover co-digested with cowdung (30:30:40 dry weight basis). 
1 Experiment of this work was designed to investigate the fertilizer prospects of digestate from

2 of certain surplus bioenergy feedstock. Therefore, target was to choose feedstock having

3 biogas production potential with abundant availability and that the resultant digestate

4 contains substantial amount of nutrient to qualify as substitute (total or partial) of inorganic

5 fertilizers. Two primary feedstocks viz. Ipomoea carnea and rice straw are abundantly

6 available biomass feedstock with potential for biogas production (Ganesh et al, 2008;

7 Deshmukh and Bartakke, 2012; Patowary et al, 2016; Contreras et al., 2012; Shitophyta et al.,

8 2015). However, $\mathrm{N}$ content of Ipomoea carnea is relatively higher that narrows down the C:N

9 ratio $(\sim 30)$ facilitating its quick anaerobic digestion during biogas production. However, rice

10 straw contains very less $\mathrm{N}$ and it has wider $\mathrm{C}: \mathrm{N}$ ratio $(\sim 66)$ that hinders its quick anaerobic

11 digestion. Hence, green gram stover ( $\mathrm{C}: \mathrm{N}$ ratio $~ 25)$ was added along with rice straw to hasten the digestion process by narrowing down the $\mathrm{C}: \mathrm{N}$ ratio. Moreover, nutritional quality of the digestate is also improved with a balanced nutrient content. Also to enhance anaerobic digestibility of these lingo-cellulosic feedstock, cowdung was also used as a co-digestion substrate. Co-digestion with animal manure increases the rate of biogas production with increased $\mathrm{AD}$ efficiency by balancing $\mathrm{C}: \mathrm{N}$ ratio, as manures are rich source of nitrogen (Zhang et al., 2013; Sebola et al., 2015). It has been established that, digestion of more than one biomass with complementary characteristics improves biogas yields due to positive synergism established in the digestion medium and improves nutrients balance in digestate (Cecchi et al., 1996; Ye et al., 2013).

Successful biogas production from Ipomoea carnea:cowdung (60:40 dry weight) and ricestraw:cowdung feedstock were reported from same research group (Patowary et al., 2016). This study reported biogas yield of 0.209 (average $67.8 \%$ methane), 0.192 (average $64.9 \%$ methane) and 0.185 (average $62.8 \%$ methane) $\mathrm{Nm}^{3} / \mathrm{kg} \mathrm{VS} /$ day from Ipomoea carnea:cowdung (60:40 dry weight), ricestraw:cowdung (60:40 dry weight) and cowdung, 
1 respectively. Biogas yield (as well as methane content) from these feedstocks are shown in

2 Figure 6 and 7 in Appendix A. Not much variation in biogas yield and methane content from

3 these findings are expected by addition of nitrogen rich pulse green gram stover $(\mathrm{C}: \mathrm{N}$ ratio 25) to ricestraw:green gram:cowdung feedstock considered in this study.

Char produced from rice husk was considered as the gasification by-product. Rice husk is one of the by-products of rice production system, forming $16-25 \%$ of the paddy processed and India produces around 24 million tonnes of rice husk per annum (Gidde and Jivani, 2007). In India, most predominant use of husk is to produce energy for rice processing through combustion in boilers. Rice husk was also shown as potential energy source through gasification route (Lin et al., 1998; Yoon et al., 2012; Nguyen and Ha-Duong, 2015). Husk is used in as fuel in industrial boilers, as ingredient in brick, steel, ceramic and cement industry, as cooking fuel in food industry, as raw material for production of silica compound (Gidde and Jivani, 2007; Baruah, 2011; Kumar et al, 2012), however, these uses are less common in India. Char of rice husk produced as energy by-product presently does not have much commercial value.

\subsection{BEBPs from anaerobic digestion reactor}

\subsubsection{Feedstock collection and preparation}

Cow dung was collected fresh from local farmer of Amolapaam village near Tezpur University. Green Ipomoea leaves were collected from nearby wetlands of University campus. Harvested rice straw and green gram stover were collected from cultivated area of Napaam village near to Tezpur University. Rice straw and green gram stover were shredded using a machete at a length of 2-3 cm and hydrolyzed for a period of 30 days as pre-treatment prior to anaerobic digestion. Green Ipomoea leaves were chopped $(4-5 \mathrm{~cm})$ prior to digestion. Cowdung was used for anaerobic digestion without any pre-treatment for both single and codigestion. 


\subsubsection{Anaerobic digestion and by-product generation}

Single and co-digested AD feedstock mentioned above was digested in laboratory based $0.25 \mathrm{~m}^{3}$ biogas reactor in the Department of Energy, Tezpur University. The Ministry of New and Renewable Energy, Government of India approved patented technology of the biogas reactor was innovated by Vivekananda Kendra - Natural Resources Development Project (VK-NARDEP), Kanayakumari, India and commercially known as Shakti Surabhi®. The reactors are equipped with an inlet for feedstock, inverted floating gas holder, water jacket, gas outlet, digestate outlet. Initially the digesters were fed to their capacity with the feedstock mixture and water in the ratio $1: 1(\mathrm{w} / \mathrm{v})$. When the gas production started, feeding was done at continuous mode at a loading of $0.2 \mathrm{~kg}$ dry weight of feedstock mixture at an interval of two days. During the digestion period, average ambient temperature was in the range of $25.6 \pm 3.6^{0} \mathrm{C}$. Digestion of three feedstocks was allowed to occur with hydraulic retention time of 30, 30 and 45 days for CD, ICD and RGC feedstocks respectively.

Anaerobic digestates were collected from the outlet of the digesters after completion of required hydraulic retention period. Part of the whole digestates collected was further processed to generate four different phases viz. whole digestate, separated solid digestate, separated liquid digestate and ash obtained from dried solid digestate as shown in Fig. 1. Separation of solid and liquid fraction of digestates was done manually using 150 micron filter bag. To prepare ash from solid digestate, separated solid digestates were air dried and combusted in open air at $450-500^{\circ} \mathrm{C}$ temperature. Ash generated was passed through 420 micron mesh to get a homogeneous sample. Whole digestate, liquid digestate and solid digestate were stored at $4^{\circ} \mathrm{C}$ before analysis. Characteristics of individual feedstock are shown in Table 3.

Table 3 Characteristics of individual feedstock

Fig.1 Schematic diagram of bioenergy by-product generation and processing 
1 Fig. 2 Anaerobic digester used for biogas production

\subsection{BEBP from gasification reactor}

Rice husk char was obtained from a local biscuit factory (Nebisco Biscuit Pvt.

Limited, Tezpur, Assam, India) that uses rice husk fired gasification unit (Ankur Type,

Model:FBG-350)for baking, roasting as well as for drying The gasifier consumes rice husk at a rate of $440 \mathrm{~kg} \mathrm{~h}^{-1}$ and operates for 8 hours a day. Char was characterized after grinding and sieving with 420 micron mesh.

\subsection{Analytical methods/protocol used for BEBP analysis}

BEBPs were analyzed for total solid, $\mathrm{pH}$, electrical conductivity, total organic carbon, macro nutrients (N, P, K, Ca, Mg, S), micronutrients (Cu, Fe, Mn, Zn, Mo, Ni), heavy metals (Cr, Pd, As, Cd, Se) and Al, Klason or acid insoluble lignin, hemicellulose and cellulose.

Standard protocols and methodologies used for BEBP analysis are briefly presented in Table

4. BEBP samples were sent to University of Nottingham, UK, laboratory for Inductively

Coupled Plasma (ICP) analysis. Total Nitrogen (TN) was done in Indian Council of

Agriculture Research Complex for North Eastern Hill Region, Umiam, Meghalaya, India and rest of the analysis was done in the Department of Energy, Tezpur University, India.

\section{Table 4 Analytical methods/protocols used for BEBP characterization}

\subsection{Statistical analysis}

Basic statistical analyses of BEBP characterization data (average, standard deviations), correlations and regression were produced using the SPSS 16.0 programme for Windows. Pearson bivariate correlation coefficients were calculated using SPSS to show the relationship between selected parameters of BEBP. Two levels i.e. $\mathrm{p}<0.05$ and $\mathrm{p}<0.01$ were considered to test statistically significant correlations between variables. Parameter means were separated using Duncan Multiple Range Test at 5\% level of significance.

\section{Results \& Discussion}


Results are presented and discussed under different sub-sections covering the characterization of BEBPs in terms of (i) total solid, $\mathrm{pH}$ and $\mathrm{EC}$, (ii) macro nutrients (TN, ammonia-N, $\mathrm{P}, \mathrm{K}, \mathrm{Ca}, \mathrm{Mg}, \mathrm{S})$, (iii) micronutrients (Cu, Fe, Mn, Zn, Mo, Ni), (iv) organic matter and (v) heavy metals. A separate table (Table 9) was added showing the characteristics of the studied BEBPs in comparison with digestates from other feedstock.

\subsection{Variability of total solid, $\mathrm{pH}$ and electrical conductivities among different options of $B E B P S$}

Solid- liquid separation of whole digestate resulted in increased TS content in the solid phases. Increase in TS content was maximum in $\mathrm{CD}_{\mathrm{S}}(163 \%)$, followed by $\mathrm{IC}_{\mathrm{S}}(98 \%)$ and $\mathrm{RGC}_{\mathrm{S}}(74 \%)$ (Table 5). TS content is a concern particularly when transported with an aim to recycle nutrients to crop field, as it is reported that, cost of transportation is reduced to half with an increase in TS by 5\% (Noone, 1990). Lower TS of whole (11.3-13.5\%) and liquid (0.7-3.1\%) digestates makes these preferable options only for in situ agricultural application.

All the BEBPs were characterized by alkaline $\mathrm{pH}$ with a phase wise variation among them (Table 5). In whole, solid and liquid digestates, marginal to moderate alkalinity was observed due to volatile fatty acid degradation and production of $\mathrm{NH}_{4}{ }^{+}-\mathrm{N}$ through organic $\mathrm{N}$ mineralization during digestion (Gomez et al., 2007; Tambone et al., 2009). Compared to whole (7.3-8) and solid (7-8.1) digestates, liquid digestates were characterized by higher $\mathrm{pH}$ (8.5-8.9), attributed to predominance of $\mathrm{NH}_{4}-\mathrm{N}$. By-products in ash and char phase show higher alkaline $\mathrm{pH}(9.7-10.3)$ due to the presence of oxides and carbonates of both alkali and alkaline earth metals such as $\mathrm{K}, \mathrm{Ca}$ and $\mathrm{Mg}$ (James et al., 2012).

Immediate effect of application of digestates having high $\mathrm{pH}$ is to reduce soil acidification (Fuchs et al., 2008; Makadi et al., 2012). However, its long term application may be favourable in alkaline soil to bring down the soil $\mathrm{pH}$ eventually. Upon application of 
1 digestates with relatively high concentration of $\mathrm{NH}_{4}{ }^{+}, \mathrm{NH}_{4}{ }^{+}$undergoes microbial nitrification

2 (conversion of $\mathrm{NH}_{4}{ }^{+}$to $\mathrm{NO}_{3}^{-}$) and in the process $\mathrm{H}^{+}$ions are released into soil solution

3 (Manitoba, 2013). Thus application of high $\mathrm{pH}$ digestate may lower soil $\mathrm{pH}$. With increase in

4 soil acidity, minerals like $\mathrm{P}$ and micronutrients become more solubilised and thus bio-available.

5 In this way, application of whole, solid and liquid digestates can help regulating soil acidity and

6 thereby nutrients availability. Alkaline $\mathrm{pH}$ of digestate in ash phase and char indicates their

7 suitability as alternative agricultural liming material such as lime, slag, quick lime and hydrated

8 lime in acidic soil.

9 Table 5 Total solid, $\mathbf{p H}, \mathrm{EC}, \mathrm{N}, \mathrm{NH}_{4}{ }^{+}-\mathrm{N}, \mathrm{P}, \mathrm{K}$, Total organic carbon and TOC:TN of 10 BEBPs bound nutrients (Massaccesi et al., 2013). Digestate processing resulted in significant variation in EC among different options of digestate application. Higher EC was found for whole (3.8-7.2 $\left.\mathrm{mS} \mathrm{cm}^{-1}\right)$ and liquid (3.4-9.3 $\left.\mathrm{mS} \mathrm{cm}^{-1}\right)$ digestates, with marginal variation 

tends to impart phyto-toxic effect particularly during seedling establishment hindering further

yield attributing factors. But the inhibiting effect may not be adequate if dilution of salt occurs after mixing with soil (Jorgensen et al., 2009). Though no marginal value of EC for agricultural application of digestate was specified, however, EC in the range of 5-10 $\mathrm{mScm}^{-1}$ is considered "High" in case of vermicompost (Fleming, 2006). Considering this criterion, care may be taken before soil application of whole $\left(7.2 \mathrm{mS} \mathrm{cm}^{-1}\right)$ and liquid $\left(9.3 \mathrm{mS} \mathrm{cm}{ }^{-1}\right)$ phase of Ipomoea digestates, as it had significantly higher EC than the other BEBPs.

\section{Fig. 3 Electrical conductivity of the BEBPs}

\subsection{Variability of plant nutrients concentration among different options of BEBPS}

\subsubsection{Macronutrients (TN, Ammonia-N, P, K, Ca, Mg, S)}

Effect of digestate processing was prominent as seen on phase wise variation of $\mathrm{TN}$ in different digestate options. Digestates in ash (7.54-11.62 $\mathrm{g} \mathrm{kg}^{-1}$ of FM) and solid (2.60-4.71 $\mathrm{g}$ $\mathrm{kg}^{-1}$ of FM) phases have higher TN followed by whole (1.30-2.72 $\mathrm{g} \mathrm{kg}^{-1}$ of FM). TN of whole and solid digestates was found to have marginal variation. Comparable TN in solid and whole digestates indicates presence of $\mathrm{N}$ remaining bound as organic $\mathrm{N}$ in solid particles (Nardin et al., 2014). However, TN of liquid digestates of all feedstocks was significantly lower (0.25$2.18 \mathrm{~g} \mathrm{~kg}^{-1}$ of $\left.\mathrm{FM}\right)$.

BEBP's also showed variation of TN with respect to feedstock (Table 5). Ipomoea containing digestates showed highest TN amongst all options. The solid phase of Ipomoea digestates showed highest TN $\left(4.7 \mathrm{~g} \mathrm{~kg}^{-1} \mathrm{FM}\right)$ followed by its whole phase $\left(2.7 \mathrm{~g} \mathrm{~kg}^{-1} \mathrm{FM}\right)$. Higher TN concentration of Ipomoea digestates may be attributed to the presence of Indolizidine alkaloids such as swainsonine and calystegines in Ipomoea leaves (Hueza et al., 2005; Schimming et al., 2005). Indolizidine alkaloids are benzene containing alkaloid, where benzene ring is fused to a five carbon ring through sharing of an $\mathrm{N}$ atom (Seigler, 1995). TN 
1 of the BEBPs under study revealed lower value than that of digestates from pig, municipal

2 sludge, cowdung, cowdung and glycerine mixture (Table 9). However, TN was found to be higher than digestate from human excreta and co-digested agro-residue (maize \& grass clover) (Gell et al., 2011; Johansen et al., 2013). Considering minimum recommended TN concentration $\left(10 \mathrm{~g} \mathrm{~kg}^{-1} \mathrm{DM}\right)$ in organic fertilizer (vermicompost) as per Indian Fertilizer (control) order, 1985, BEBPs except $\mathrm{CD}_{\mathrm{A}}, \mathrm{RGC}_{\mathrm{W}}$ and liquid digestates fulfil the minimum $\mathrm{TN}$ requirement of organic fertilizer. It is seen that, on the basis of $\mathrm{TN}$, application of Ipomoea based digestates seems to be a suitable consideration in all phases, though there is phase wise variation, compared to other BEBPs.

Considering lower total $\mathrm{N}$ concentration $\left(0.25-2.18 \mathrm{~g} \mathrm{~kg}^{-1}\right.$ of $\left.\mathrm{FM}\right)$ in liquid digestates, their fertilizer application may not be adequate to match crop $\mathrm{N}$ demand. Fulfilling total $\mathrm{N}$ requirement of the crops through application of only liquid digestate would therefore require large quantity of fertilizer. Table 11 presented at the end of this manuscript shows the quantity of liquid digestates required to fulfil crop $\mathrm{N}$ demand (in comparison with whole, solid and ash digestates) of a typical crop rotation with serial, pulse and oil seed. Need of higher application dose with liquid digestate would require storage of digestate for substantial period of time creating other logistic and management issues. Alternatively, liquid digestates could be supplemented with additional source of $\mathrm{N}$ depending upon the crop demand.

$\mathrm{TN}$ in mineralized form i.e. $\mathrm{NH}_{4}-\mathrm{N}$ is an important parameter to understand the status of readily available $\mathrm{N}$ fraction in organic fertilizer. The variations of $\mathrm{NH}_{4}-\mathrm{N}$ among different options of BEBPs with respect to feedstock and phase are significant as seen in Table 5.

Consistently Ipomoea based digestates showed higher $\mathrm{NH}_{4}-\mathrm{N}$ content in all phases.

Compared to $\mathrm{NH}_{4}-\mathrm{N}$ content of whole and solid phase of $\mathrm{CD}$ (165 and $123 \mathrm{mg} \mathrm{kg}^{-1} \mathrm{FM}$ respectively) and RGC (138 and $116 \mathrm{mg} \mathrm{kg}^{-1} \mathrm{FM}$ respectively) digestate, IC containing whole and solid digestate (790 $\mathrm{mg} \mathrm{kg}^{-1}$ and $399 \mathrm{mg} \mathrm{kg}^{-1} \mathrm{FM}$ respectively) showed significantly 
1 higher $\mathrm{NH}_{4}-\mathrm{N} . \mathrm{RH}_{\mathrm{C}}$ showed lowest $\mathrm{NH}_{4}-\mathrm{N}$ among the BEBPs (48 $\left.\mathrm{mg} \mathrm{kg}^{-1} \mathrm{FM}\right) . \mathrm{NH}_{4}-\mathrm{N}$

2 concentrations in the BEBPs were found to be lower than the concentration at which (1500

$\mathrm{mg} \mathrm{kg}^{-1}$ ) its inhibitory effect on germination has been reported (Salminen et al., 2001).

It is seen that, liquid digestates shared larger fraction of $\mathrm{NH}_{4}-\mathrm{N}$ of the whole digestate (61-91\%) compared to that of solid fractions (12-41\%) (Fig. 4) after solid-liquid separation. whereas digestates in ash phase contained minor portion of $\mathrm{NH}_{4}-\mathrm{N}(1.4-4.7 \%)$ of whole digestates. Moller et al., 2002 also reported majority of mineralized $\mathrm{N}$ ending up in separated liquid fraction after solid liquid separation of manure. $\mathrm{NH}_{4}-\mathrm{N}$ available in solid digestates is still significant probably due to higher moisture content in the solid fractions which was in the range of $70-77 \%$. Higher availability of the $\mathrm{NH}_{4}-\mathrm{N}$ fraction into liquid fraction makes it a readily usable plant nutrient source, as $\mathrm{NH}_{4}-\mathrm{N}$ can be absorbed by plants instantly (WRAP, 2012)

Fig.4 $\mathrm{NH}_{4}-\mathrm{N}$ partitioning in solid/liquid/ash phase of digestates

Conservation of $\mathrm{NH}_{4}-\mathrm{N}$ in digestates is often affected by its management practices. In

Indian scenario, the most common management and transportation practice of digestate adopted by rural household biogas users is to keep it in uncovered earthen pits and its direct release into crop area through unlined channel. This practice increases the possibility of reduced nutrient value of digestate through ground leaching or gaseous emission. Considering the predominance of mineralized nitrogen in liquid and whole digestates, storage for a longer duration is not encouraged and their more suitable use as fertilizers could be recommended instead of organic amendment. Alternatively, liquid digestates could be further processed for value addition. In this context, recovery of ammonia through production of recoverable product such as of struvite $\left(\mathrm{MgNH}_{4} \mathrm{PO}_{4} \cdot 6 \mathrm{H}_{2} \mathrm{O}\right)$, which is an ammonia and phosphorus 

nutrient after $\mathrm{N}$. This finding is supported by previous studies on digestates from farm, agro industrial, sewage sludge and food waste (Alburquerque et al., 2012; Zirkler et al., 2014). There is a variation of $\mathrm{K}$ among different options of BEBPs. Highest concentration of $\mathrm{K}$ was observed in digestates in ash phase (9.53-15.53 $\left.\mathrm{g} \mathrm{kg}^{-1} \mathrm{FM}\right)$ and liquid digestates $(0.69-1.61 \mathrm{~g}$ $\mathrm{kg}^{-1} \mathrm{FM}$ ) were found to be poor in $\mathrm{K}$. High $\mathrm{K}$ of ash phases may be attributed to the presence of oxides and carbonates of K. Among the ash phases, Ipomoea based ash digestate showed suitability as $\mathrm{K}$ source with highest $\mathrm{K}\left(15.35 \mathrm{~g} \mathrm{~kg}^{-1} \mathrm{FM}\right)$ concentration. $\mathrm{K}$ concentration in digestates ash phase was found to be higher than that of municipal sludge, cowdung, pig, food waste and human excreta based digestate (Table 9).

Ipomoea digestates showed significantly higher K concentration in all application options, following the similar trend as in case of TN (Table 5). Ipomoea leaves have been shown to be rich in oxalate alkaloid which mainly corresponds to K or Na salt of oxalic acid that may attribute to higher K concentration (Meira et al., 2012).

Similar to K, P concentration was highest in ash phase of digestates $\left(3.78-8.42 \mathrm{~g} \mathrm{~kg}^{-1}\right.$ FM), whereas liquid digestates had the lowest $\mathrm{P}\left(0.06-0.19 \mathrm{~g} \mathrm{~kg}^{-1} \mathrm{FM}\right) . \mathrm{CD}_{\mathrm{A}}$ contained highest $\mathrm{P}$ concentration among all BEBPs. However, $\mathrm{P}$ concentrations in the BEBPs are remarkably lower than $\mathrm{P}$ concentrations of digestate from swine manure, co digested crop residue and municipal sludge (Tambone et al., 2010; Gell et al., 2011). Therefore, to match $\mathrm{P}$ requirement of different crops, different quantity of auxiliary $\mathrm{P}$ source may have to be added along with BEBP. Table 11 shows the estimation of $\mathrm{P}$ and $\mathrm{K}$ that could be made available from BEBPs, applied at a dose to fulfil crop $\mathrm{N}$ demand of a typical crop rotation with serial, pulse and oil seed. Table 11 also shows additional $\mathrm{P}$ and $\mathrm{K}$ required to be added with BEBP to match their $\mathrm{P}, \mathrm{K}$ requirement. $\mathrm{P}$ enrichment of digestate can be done with rock phosphate 

property of digestate or biochar have been set. However, as per the Indian Fertilizer (control) order, 1985, organic fertilizer in the form of vermicompost should have a minimum $\mathrm{K}$ and $\mathrm{P}$ content of $0.66 \%$ and $0.34 \%$ dry weight respectively. Considering this criteria, $\mathrm{K}$ concentrations in all ash digestates, $\operatorname{ICD}_{\mathrm{W}}\left(13.61 \mathrm{~g} \mathrm{~kg}^{-1} \mathrm{DM}\right)$ and $\operatorname{ICD}_{\mathrm{S}}\left(6.94 \mathrm{~g} \mathrm{~kg}^{-1} \mathrm{DM}\right)$ digestates and $\mathrm{RH}_{\mathrm{C}}$ are in the required range. Similarly, minimum desirable concentration of

$7 \quad \mathrm{P}$ was fulfilled by all ash digestates and $\mathrm{ICD}_{\mathrm{S}}$ digestates. It may be noted that, $\mathrm{K}$ and $\mathrm{P}$ content of CD and RGC digestates in whole, solid and liquid phase are not sufficient to fulfil minimum criteria of $\mathrm{P}$ and $\mathrm{K}$ content of an organic fertilizer. On the other hand, only Ipomoea based digestates in whole, solid and ash phase is suitable to be considered as organic $\mathrm{P}$ and $\mathrm{K}$ fertilizer. Nevertheless, in case of by-products generated through $\mathrm{AD}$, concern for nutrient dilution or loss is minimal. Moreover, risk of non availability of nutrients is counterbalanced by the fact that, mineralization of organic fraction takes place making nutrients more bio-available in digestates (Lansing et al., 2010). Table 6 shows fertilizer values $\left(\mathrm{N}: \mathrm{P}_{2} \mathrm{O}_{5}: \mathrm{K}_{2} \mathrm{O}\right)$ of the BEBPs.

\section{Table $6 \mathrm{~N}: \mathrm{P}_{2} \mathrm{O}_{5}: \mathrm{K}_{2} \mathrm{O}$ value of the BEBPs}

Processing of BEBPs through solid liquid separation and combustion resulted in remarkable variation in secondary macronutrient $(\mathrm{Ca}, \mathrm{Mg}, \mathrm{S})$ distribution among different phases. The relative abundance of secondary macro nutrients in AD by-products were as follows; $\mathrm{Ca}>\mathrm{Mg}>\mathrm{S}$. Phase wise, $\mathrm{Ca}, \mathrm{Mg}$ and $\mathrm{S}$ showed a decreasing trend as follows; ash > solid > whole > liquid digestates. Rice husk char also followed similar trend of relative abundance of nutrient, though the concentrations were found to be remarkably lower than the other BEBPs considered. Among all the BEBPs, $\mathrm{Ca}$ and $\mathrm{S}$ were highest in ash phase of Ipomoea containing digestates, whereas $\mathrm{CD}_{\mathrm{A}}$ showed highest concentrations of $\mathrm{Mg}$. 

neutralizing agent or liming agent in acidic soil, however, no report on use of digestate ash as fertilizer could be found.

Table 7 Secondary macronutrients and micronutrients $(\mathrm{Ca}, \mathrm{Mg}, \mathrm{S}, \mathrm{Fe}, \mathrm{Mn}, \mathrm{Zn}, \mathrm{Cu}, \mathrm{Mo}$, $5 \quad \mathrm{Ni}$ ) in the BEBPs

\subsubsection{Micronutrients $(\mathrm{Cu}, \mathrm{Fe}, \mathrm{Mn}, \mathrm{Zn}, \mathrm{Mo}, \mathrm{Ni})$}

In all the BEBPs, predominant micronutrients were $\mathrm{Fe}>\mathrm{Mn}>\mathrm{Zn}>\mathrm{Cu}>\mathrm{Ni}>\mathrm{Mo}$ in their decreasing order of abundance. It was observed that, relative abundance of the micronutrients did not vary with respect to feedstock and processing conditions (separation and ashing). Micronutrients followed a decreasing trend of relative abundance as follows; ash >solid $>$ whole >liquid digestates (Table 7). Rice husk char also followed similar trend of relative abundance of nutrient, though the concentrations were found to be remarkably lower than other BEBPs considered.

Indian Fertilizer regulations did not specify the the minimum requirement of micronutrient in organic fertilizer. However, Table 9 shows higher micronutrient concentration of ash digestates compared to digestates from co digested crop residue and food waste (Zirkler et al., 2014; Krishnasamy et al., 2014). Recent studies indicated temporal variations in nutrient content of heterogeneous feedstock based digestates such as animal manure and sewage sludge (Zirkler et al., 2014). On the other hand, probability of elemental variation is reported to be less in plant biomass based organic fertilizer. Therefore, there is need of continuous monitoring of nutrient dynamics before considering fertilizer application of such digestates.

\subsection{Variability of organic matter among different options of BEBPs}

Assessment of organic matter is necessary to define suitability of fertilizer as organic amendment. There were feedstock and phase wise variations of organic matter (as TOC) in 
1 different options of BEBPs. Rice straw:green gram based whole (43.33\% DM) and solid

2 (44.54\% DM) digestates showed highest organic matter because of lingo cellulosic nature of

3 feedstock followed by Ipomoea based whole (40.1\% DM) and solid (38.5\% DM) digestates.

$4 \quad$ On fresh weight basis, TOC of solid digestates were remarkably higher than the other phases

5 of digestates. Increased TOC of solid digestates could be attributed to increased dry matter

6 content in solid phases. Liquid phase of BEBPs showed significantly lower TOC $(0.18-2 \%)$,

7 as the dry matter content is minimum (0.7-3\%). Insignificant organic matter content of liquid

8 digestates indicates their limitation as organic amendments (Nkoa, 2014).

From users' perspective, concern about digestate application is its low organic carbon content that remains available for crops and microbes (Arthurson, 2009, Johansen et al., 2013). Nevertheless, TOC of whole and solid digestates were higher than recommended TOC content of vermicompost (18\% DM) as per the Indian Fertilizer (Control) order, 1985. TOC of the BEBPs were also comparable with other digestates recommended as organic fertilizer such as pig slurry, human excreta and food waste (Table 9).

In organic fertilizer, $\mathrm{C}: \mathrm{N}$ ratio plays an significant role in regulating organic matter mineralization in soil (Barrett and Burke, 2000). In the present study, phase wise variation of C:N ratio is prominent. Whole (16.03-40.99) and solid (17.95-40.14) digestates have distinctly higher $\mathrm{C}: \mathrm{N}$ compared to $\mathrm{C}: \mathrm{N}$ ratio of liquid digestates (0.72-0.92). Low $\mathrm{C}: \mathrm{N}$ ratio of liquid digestates is due to the minimum organic content in separated liquid fractions.

In general, for plant and manure based digestates, a $\mathrm{C}: \mathrm{N}$ ratio of 12-13 is reported (Gell et al., 2011; Walsh et al., 2012). However, in this study, for ICD and CD digestates (whole and solid phases), slightly higher value was found (16-17). The main cattle feed used in the study area is rice straw, which may have resulted in higher $\mathrm{C}: \mathrm{N}$ of the digestates generated from co digested cowdung feedstock. In agro residue based digestate i.e. RGC, wide $\mathrm{C}: \mathrm{N}$ ratio resulted in whole and solid phase (40) due to $\mathrm{C}$ conservation compared to 
1 manure digestates. Rice husk char showed highest C:N (143) attributed to recalcitrant organic

2 fraction conserved during gasification (Abrishamkesh et al., 2015).

Application of digestates with unbalanced $\mathrm{C}: \mathrm{N}$ ratios can have detrimental impact on

soil microbial community influencing $\mathrm{N}$ turnover in agriculture (Johansen et al., 2013).

5 Excess of degradable organic matter with respect to $\mathrm{N}$ leads to $\mathrm{N}$ immobilization in microbial

6 mass and limits its crop availability (Alburquerque et al., 2012). On the other hand, excess $\mathrm{N}$

7 with respect to organic fraction can help ready uptake of plants nutrients, but nutrients value

of BEBPs may be compromised through ammonia volatilisation (Alburquerque et al., 2012).

Ammonia rich condition can further drive chemo-autotrophs nitrifiers for rapid nitrification and as a result nitrate leaching from soil may occur (Arthurson et al., 2009). Considering these criteria, Ipomoea and cowdung based digestates appear to be suitable fertilizer in all application options. However, in case of whole and solid phase of RGC, pre-treatment (mechanical size reduction) prior to anaerobic digestion may be recommended. Such pretreatment increases surface area facilitating hydrolysis and cell wall rupturing, making organic matter readily available for microbial degradation (Zhang and Zhang, 1999; Hendriks et al., 2009). Otherwise, addition of $\mathrm{N}$ rich inoculums with input feedstock to provide appropriate nutrient balance may be helpful (Mussoline, 2013). Lowest C:N ratio indicates suitability of liquid digestates for short term and immediate soil application as plant nutrient source instead of soil conditioner. general, feedstock processed through anaerobic digestion is characterized by preservation of recalcitrant fractions (lignin) and extensive reduction of cellulose and hemicelluloses. In present study, as determined on the whole and solid digestates, feedstock type did not show 
1 digestates. However, there was significant variation in cellulose content of different

2 feedstock. Whole and solid phase of RGC digestates had highest cellulose (27\%) content,

3 followed by ICD (16-11\%) and CD (2.4-2.5\%) whole and solid digestates (Fig. 6).

$4 \quad$ Fig.5 Acid insoluble lignin (Klason lignin), Hemicellulose and Cellulose content of the

$5 \quad$ BEBP (whole and solid digestates)

6

Presence of recalcitrant fraction determines the ability of an organic matrix to contribute actively to the soil organic matter in a short period (Adani and Tambone, 2005). Immediate availability of plant nutrients from cellulose and lignin rich digestate would be limited. However, application of these may be useful as they act as humus precursor in due course (Lorenz et al., 2007). Maturity of organic matrix defined by "maturity indices" indicates organic fertilizer stability in soil. "Humification index (HI)" is a maturity index estimated as cellulose+hemicellulose)/lignin ratio. Though the index is mostly used for compost maturity determination, it is also used in relation with digestate (Tambone et al., 2009; Teglia et al., 2011b). In undigested feedstock, HI index remains higher than 1 . HI is lowered below 1 in digestate due to relatively lower degradation of lignin in relation to cellulose and hemicelluloses. Decrease in HI from 1.36 in feedstock (energetic crops, cow slurry, agro-industrial waste and organic fraction of municipal solid waste) to 0.82 was reported by Tambone et al., 2009. Though no separate threshold value has been assigned to indicate digestate maturity, $\mathrm{HI}<0.5$ is used to describe maturity of digestate Tambone et al., 2009). In the present study, RSG based digestates, both solid and whole phase were found to be immature with HI 0.70 , followed by mature CD whole $(0.10)$, solid $(0.10)$ and ICD whole (0.27) and solid (0.44) digestates. Therefore, need of post treatment (aerobic composting) may be recommended for agro residue based digestates to further degrade recalcitrant organic. Otherwise, there is a possibility of reduced availability of plant nutrients because of limited microbial activity on recalcitrant fractions of such digestate (Ernst et al., 2008). 


\subsection{Heavy metals (Cr, Pb, As, Cd, Se) and Al among different options of BEBPs}

In anaerobic digestion, heavy metals and organic pollutants arising from input

feedstock may end up in the by-products or may be formed as intermediate product during course of conversion (Ciavatta et al., 1993; Kupper et al., 2014). Application of digestate with heavy metal exceeding regulatory limit may induce their partitioning to crop and consequently to the higher components of the food chain.

Cr was found as the most prevalent heavy metal in the BEBPs, followed by $\mathrm{Pb}, \mathrm{As}$,

Cd and Se (Table 9). Digestate processing had influence on heavy metal distribution among various phases. Ash phases had the highest concentration of heavy metal. Liquid digestates were found to be significantly lower in heavy metal concentration. The actual amount of different heavy metals accumulated in the soil depends upon the rate of digestate application (Tampio et al., 2016). The load of heavy metal on soil would be different for different application option of BEBPs due to variation in application dose based on BEBPs N concentration. If we consider a BEBP application rate of $100 \mathrm{~kg} \mathrm{ha}^{-1} \mathrm{~N}_{\text {year }}{ }^{-1}$, subsequent accumulation of various heavy metals $(\mathrm{Cr}, \mathrm{Pb}, \mathrm{As}, \mathrm{Cd}))$ upon their soil application were estimated taking into account the concentration of these heavy metals in the BEBPs. It was estimated that, to meet the requirement of $100 \mathrm{~kg} \mathrm{ha}^{-1} \mathrm{~N}$ year ${ }^{-1}$, using different options of BEBPs, subsequent building up of $\mathrm{Cr}, \mathrm{Pb}$, As and $\mathrm{Cd}$ would be in the range of 0.92-288, 2.20-164, 0.26-140, 0.05-51.54 $\mathrm{g} \mathrm{ha}^{-1}$ year $^{-1}$ respectively. Among all the application options, maximum heavy metal $(\mathrm{Cr}, \mathrm{Pb}, \mathrm{As}, \mathrm{Cd})$ load will be accumulated for $\mathrm{CD}_{\mathrm{A}}$ followed by $\mathrm{IC}_{\mathrm{A}}$, $\mathrm{RGC}_{\mathrm{A}}$ and $\mathrm{RH}_{\mathrm{C}}$. On the other hand liquid digestates showed least environmental concern in terms of heavy metals built up in soil.

National regulations in many countries like UK, Spain and Germany prohibit the use of digestates if the concentration of one or more heavy metal exceeds certain limit. As per Indian fertilizer regulation on organic fertilizer quality standard, maximum permissible limit 
1 has been set for $\mathrm{Cd}, \mathrm{Cr}, \mathrm{Ni}$ and $\mathrm{Pb}$ in case of vermicompost, which are 5, 50, 50 and $100 \mathrm{mg}$

$2 \mathrm{~kg}^{-1}$ respectively. It is seen that, with respect to heavy metals, the concentrations in BEBPs were far lower than the threshold value set for these four heavy metals. Concentrations of heavy metals were also found to be lower than similar by-products of different origin (Table 9) such as digested sewage sludge and maize digestate.

Al phytotoxicity is the major constraint for crop production in $67 \%$ of the total global acid soil (Eswaran et al., 1997), to which North East India belongs. The most easily recognized symptom of Al toxicity is the inhibition of root growth in plants and most plants are sensitive to micromolar concentration of Al (Delhaize and Ryan, 1995). With respect to Al, application of whole, solid and ash digestates could be a concern in acid soil, as its concentration was found to be relatively high in the BEBPs. Though literature does not give Al concentration of digestate of various sources, BEBPs under study contained higher Al concentration (1.2-3.3 $\left.\mathrm{g} \mathrm{kg}^{-1}\right)$ than poultry digestate $\left(50-90 \mathrm{mg} \mathrm{kg}^{-1}\right)$.

Table 8 Heavy metals $(\mathrm{Cr}, \mathrm{Pb}, \mathrm{As}, \mathrm{Cd}, \mathrm{Se})$ and $\mathrm{Al}$ in BEBPs

\section{Table 9 Comparison of the BEBPs with similar by-products}

In addition to the nutritional status, apprehension on application of BEBP concerning health hazard is important for digestate utilization as fertilizer. The probable factors attributing to microbial contamination of digestate are origin of feedstock and operating conditions of digestion such as pre-treatment, temperature and pH (Sahlstrom 2003; Owamah et al., 2014). In general digestates from human excreta, sewage sludge were reported to contain harmful microbes of health concern such as Klebsiella, E. coli, Salmollena (Owamah et al., 2014, Nkoa et al., 2014). Feedstocks considered in this study are plant and manure based digestates. Report on presence of harmful microbes in digestates from such feedstock could not be found. However, independent investigation on microbial analysis of the BEBPs is required to understand health implications of their applications. 


\subsection{Statistical analysis}

Relationships between TN, P, K, macro and micro nutrients and heavy metals content of BEBPs were determined by regression analysis. Pearson correlation test for TS of the BEBPs correlated positively with $\mathrm{P}\left(\mathrm{r}^{2}=0.78\right)$ and negatively with $\mathrm{K}\left(\mathrm{r}^{2}=-0.41\right)$ of the BEBPs. These significant correlations show that $\mathrm{P}$ is associated with the dry matter fraction of the by-products, whereas, $\mathrm{K}$ mainly remains in the liquid fraction. Positive significant correlation of EC with K confirms K's association with the liquid fraction. Significant positive correlations are also found between TS content of the BEBPs and secondary macro nutrients such as $\mathrm{Ca}, \mathrm{Mg}$ and $\mathrm{S}$ of the BEBPs at $\mathrm{r}^{2} 0.81,0.82$ and 0.81 respectively $(\mathrm{p}<0.01)$, which indicates their association in particulate fraction of the BEBPs. Since $\mathrm{Ca}$ and $\mathrm{Mg}$ are linked with solid fraction of the digestates, they also showed significant negative correlation with $\mathrm{K}$. Presence of particulate $\mathrm{P}$ or $\mathrm{P}$ in bound form along with $\mathrm{Ca}$ and $\mathrm{Mg}$ was indicated by its strong positive correlation with $\mathrm{Ca}$ and $\mathrm{Mg}$. In the BEBPs, organic fraction is particularly related to the dry matter fraction as seen from significant correlation of TOC with TS at $\mathrm{r}^{2}$ 0.79. TOC also strongly correlated with $\mathrm{Ca}$ and $\mathrm{Mg}$.

Preferential association of $\mathrm{NH}_{4}-\mathrm{N}$ with the liquid fraction of digestate was indicated by its positive significant correlation of EC at $\mathrm{r}^{2} 0.82$. As EC indicates extent of mineralization, therefore, increase in $\mathrm{NH}_{4}-\mathrm{N}$ also increases $\mathrm{EC}$ of the by-products. This finding is supported by previous findings (Suresh et al., 2009; Yang et al., 2006). Present study also found number of highly significant correlation among the micro and heavy metals. Table 10 shows the statistically significant correlations among selected parameters of BEBPs. Table 10 Significant correlations among selected parameters of BEBPs

\subsection{Application of BEBP with special reference to Indian farming}



relevant in Indian context. Considering the present scenario of Indian agriculture with an increased import of chemical fertilizer, BEBP as its supplement seems to be beneficial. This

has been realized in India and therefore there are several efforts to popularize the digestate application from biogas system. National Biogas and Manure Management Programme (NBMMP) of Government of India is one of the examples with a target to reduce dependency of synthetic fertilizer by the use of digestate in agriculture.

Presently, there are nearly 4.8 million (as on January, 2016) biogas plants installed in India (MNRE, Govt. of India); and there is ample opportunities for biogas users to undertake organic farming using its by-product. Promising results of agricultural application of digestate were reported in Indian agriculture (Gnanamani et al., 1992; Singh et al., 2007; Hazarika et al., 2015). However, considering the number of plants installed, wider application of digestate as nutrient resourse is limited. Study shows that, there is knowledge gap around valorization opportunities related to digestate use (Raha et al., 2015). Difficulty in handling is another major barrier limiting digestate utilization. Digestate is left for sun drying for volume reduction, which causes nutrient loss (Raha et al., 2015). There is loss of nutrient also through leaching from storage of digestate in unlined earthen pit (Gupta et al., 2003; UGC-UKIERI project report, 2015).

Realizing mismanagement associated with digestate use, present investigation was carried out to address these issues concerning the application prospects of BEBP specifically from rural Indian perspective. Knowhow generated in this research on nutritional status of bioenergy by-product shows prospects of digestate up-gradation through its processed application in agriculture to increase its usefulness. Based on the nutritional status of BEBP which is discussed before and some realistic considerations, an quantitative estimation was made on requirement of different BEBPs options based on $100 \%$ supplement of $\mathrm{N}$ in a typical 
1 Indian crop rotation (Serial, Pulse, Oilseed) which is presented in Table 11. A comparative assessment of different options of BEBPs application in terms of processed and unprocessed BEBP requirement, their $\mathrm{P}, \mathrm{K}$ availability, biogas plant size needed to generate the required amount of BEBP is shown in Table 11.

\section{Table 11 Comparative assessment of different options of BEBPs application in a typical} Indian crop rotation

Amount of BEBP requirement for fertilization would vary depending upon the $\mathrm{N}$ concentration in the BEBP. In general, less amount of digestate in solid phase is required compared to other phases of BEBPs for an equal amount of $\mathrm{N}$ supplementation. Application of digestate in solid phase with enhanced nutrient value will be advantageous in terms of both in situ and intermediate storage and long range transport due to reduced volume. On the other hand, fulfilling total $\mathrm{N}$ requirement of the crops through application of digestate in liquid phase would require large quantity, due to their low total nutrient content. This implies need of storage of digestate for substantial period of time to generate the required amount. Storage in case of liquid digestate would require coverage of storage tanks to minimize emission loss. Alternatively, liquid digestates could be supplemented with additional source of $\mathrm{N}$ depending upon the crop demand. Liquid digestate can be transported to nearby farmland through irrigation tunnels, where they can be directly applied using conventional irrigation technologies. Though ash represents concentrated form of nutrients, requirements of whole digestate would be fairly large to generate ash, as ash percentage is only $1.6-4.7 \%$ of whole digestate. Application of ash digestate would be justifiable, if farmers use the secondary energy recovery route from solid digestate by preparing solid fuels or briquette.

Table 11 also shows estimation of $\mathrm{P}$ and $\mathrm{K}$ that could be made available from BEBPs, applied at $100 \%$ supplement of N. We found that, for digestates in whole, solid and liquid phase, different quantity of auxiliary P source have to be added along with BEBP options to 
1 match P requirement of rice, pulse and oil. However, all options of BEBP at $100 \% \mathrm{~N}$

2 supplement except $\mathrm{ICD}_{\mathrm{w}}, \mathrm{RGC}_{\mathrm{w}}$ and $\mathrm{CD}_{\mathrm{s}}$ would simultaneously fulfil the $\mathrm{K}$ requirement of

3 the crops. Parallel supply of $\mathrm{P}, \mathrm{K}$ and other micronutrients from BEBP application will

4 reduce additional requirement of $\mathrm{P}$ and $\mathrm{K}$ fertilizer.

5 The estimation is made for a typical rural Indian farmland of 1 hectare area.

6 Accordingly, handling and processing of by-product could be managed without substantial

7 technological input considering fertilization at such small scale farming. However, at large

8 scale there is a requirement to find out the economics considering digestate processing

9 technique, storage and application method for economic viability.

\section{Conclusions}

In this study, based on nutritional status, we evaluated fertilizer suitability of 13 bioenergy by-product from different feedstock with various options of application. Byproducts processing (solid liquid separation and ashing) generate fractions with significantly different nutrient value and can be employed as measure for successful nutrient management. Organic matter and nutrient status of the whole, solid and ash digestates suggest their potential agricultural application. On the other hand, liquid digestates were relatively nutrient poor, though rapid plant uptake could be ensured due to higher availability of $\mathrm{NH}_{4}-\mathrm{N}$. Ipomoea based digestates showed suitability as fertilizer with comparatively higher plant nutritional content. Whereas, nutrient supplementation or further processing (stabilization) is required in case of BEBPs (rice straw:green gram stover:cowdung whole and solid digestates) with unstable organic fraction to maximize the benefit. Heavy metal contents of the BEBPs were found to be within the permitted range. However, higher $\mathrm{Al}$ content of the BEBPs in whole, solid and ash phase can be a concern in acid soil.

Utilization of by-products of bioenergy system would act as integrating link between energy, environment and agriculture. However, as there is significant variability in nutrient 
1 contents in BEBPs with respect to feedstock and processing, analysis is necessary before

2 integration of BEBPs into fertilization programmes. Improved regulations and recommendations concerning environmental perspective and market focused approach would help to promote broader acceptance and sustainable outlets for by-products of bioenergy.

\section{Acknowledgements}

7 This work was supported by the following grant awards: UKIERI-UGC 086 Optimising

8 Phosphate Recovery from Community Bioenergy Systems: Low Cost Sustainable Fertiliser

9 Production for Rural Communities; UK Engineering and Physical Sciences Research

10 Council - India Department of Science and Technology J000361/1 Rural Hybrid Energy

11 Enterprise Systems. We thank Dr. Helen West, School of Biosciences \& Prof Michele

12 Clarke, School of Geography from University of Nottingham and Mr. Dipal Baruah,

Department of Energy, Tezpur University for their insightful comments, suggestions and help in analysis. Acknowledgement is due to Indian Council of Agriculture Research Complex for North Eastern Hill Region, Umiam, Meghalaya, India is for their help in analysis.

\section{References} 2015.Effects of rice husk biochar application on the properties of alkaline soil and lentil growth. Plant Soil Environ. 61, 475-482.

Abubaker, J., Risberg, K., 2012. Biogas residues as fertilisers-Effects on wheat growth and soil microbial activity. Appl. Energy, 99, 126-134. humic acids. Chemosphere. 60, 1214-1221. 

undigested and anaerobically digested poultry manure on the growth and yield of maize (Zea mays, L). African J. Environ. Sci. Technol. 4, 100-107. Alburquerque, J.A., de la Fuente, C., Ferrer-Costa, F., Carrasco, L., Cegarra, J., Abad, M., Bernal, M.P., 2012. Assessment of the fertiliser potential of digestates from farm and agroindustrial residues. Biomass Bioenergy. 40, 181-189. Alfa, M.I., Adie, D.B., Igboro, S.B., Oranusi, U.S., Dahunsi, S.O., Akali, D.M., 2014. Assessment of biofertilizer quality and health implications of anaerobic effluent of cow dung and chicken droppings. Ren. Energy. 63, 681-686.

Andruschkewitsch, M., Wachendorf, C., Wachendorf, M., 2013. Effects of digestates from different biogas production systems on above and belowground grass growth and the nitrogen status of the plant-soil-system. Japanese Soc. Grassland Sci. 59, 183-195. Annual report, 2013-14, on the Working of State Power Utilities and Electricity Departments, Power and Energy Division, Planning commission, Govt. of India http://planningcommission.nic.in/reports/genrep/rep_arpower0306.pdf Arthurson, V., 2009. Closing the Global Energy and Nutrient Cycles through Application of Biogas Residue to Agricultural Land - Potential Benefits and Drawbacks. Energies. 2, 226-242.

Bachmann, S. and Eichler-Löbermann, B., 2009. Fertilizing effect of biogas slurries. In: More sustainability in agriculture - new fertilizers and fertilization management, proceeding of 18th Symposium CIEC, Rome, Nov 2009.

Balsari P., Gioelli F., Menardo S., Paschetta E., 2010. The (re)use of mechanical separated solid fraction of digested or not digested slurry in anaerobic digestion plants. Proceedings paper published in: C.S.C. Cordovil and L. Ferreira (eds.): Proceedings of the $14^{\text {th }} 251$ Ramiran International Conference, Lisboa, Portugal. 
1 Barrett, J.E., Burke, I.C., 2000. Potential nitrogen immobilization in grasslandsoils across a soil organic matter gradient. Soil Biol. Biochem. 32,1707-1716.

Baruah, D.C., 2011. Turning restaurants in Assam greener, Akshay Urja. http://mnre.gov.in/file-manager/akshay-urja/july august2011/EN/Turning\%20restaurants.pdf Bioenergy India., 2010. UNDP-GEF biomass power project of Ministry of New and Renewable Energy, Govt. of India. Winrock International India. http://www.undp.org/content/dam/india/docs/bioenergy_issue4.pdf BSI. PAS 110:2010. Specification for whole digestate, separated liquor and separated fibre derived from the anaerobic digestion of source-segregated biodegradable materials. 60p. British Standards Institution Publications.

Cecchi, F., Pavan, P., Mata-Alvarez, J., 1996. Anaerobic Co-Digestion of Sewage Sledge: Application to the Macroalgae from the Venice Lagoon. Resour. Conserv. Recy. 17, 57 66.

Chandra, K., 2005. Organic manures. Regional Centre of organic farming. Bangalore. 20http://ncof.dacnet.nic.in/Training_manuals/Training_manuals_in_English/Organicman ures.pdf

Chantigny, M.H., Angers, D.A., Bélanger, G., Rochette, P., Eriksen-Hamel, N., Bittman, S., Buckley, K., Massé, D., Gasser, M.O., 2008. Yield and nutrient export of grain corn fertilized with raw and treated liquid swine manure. Agron. J. 100, 1303-1309.

Chiew, Y.L., Spångberga, J., Baky, A., Hanssona, P.A., Jönsson, H., 2015. Environmental impact of recycling digested food waste as a fertilizer in agriculture-A case study. Resour. Conserv. Recy. 95, 1-14. 
Ciavatta, C., Govi, M., Simoni, A., Sequi, P., 1993. Evaluation of heavy metals during stabilization of organic matter in compost produced with municipal solid wastes. Bioresour. Technol. 43, 147-153.

Contreras, L.M., Schelle, H., Sebrango, C.R., Pereda, I., 2012. Methane potential and biodegradability of rice straw, rice husk and rice residues from the drying process. Water Sci. Technol. 65(6), 1142-1149.

Cundr, O., Haladova, D., 2014. Biogas yield from Anaerobic batch co-digestion of Rice straw and zebu dung. Scientia Agriculturae Bohemica. 45, 98-103.

Dahlin, J., Herbes, C., Nelles, M., 2015. Biogas digestate marketing: Qualitative insights into the supply side. Resour. Conserv. Recycl. 104, 152-161.

de Boer, H.C., 2008. Co-digestion of animal slurry can increase short-term nitrogen recovery bycrops. J. Environ. Qual., 37, 1968-1973.

Delhaize, E., Ryan, P.R., 1995. Aluminum Toxicity and Tolerance in Plants. Plant Physiol. 107, 315-321.

Demirel, B., Gol, N.P., Onay, T.T., 2013. Evaluation of heavy metal content in digestate from batch anaerobic co-digestion of sunflower hulls and poultry manure, J Mater.Cycles Waste Manage. 15, 242-246.

Deshmukh, H.V., Bartakke, G.R., 2012. Co-utilization of common weed Ipomoea carnea along with distillery waste for biogas production. Int. J. Curr. Sci. 229-240.

Eickenscheidt, T., Freibauer, A., Heinichen, J., Augustin, J., Drösler, M., 2014. Shortterm effects of biogas digestate and cattle slurry application on greenhouse gas emissions from high organic carbon grasslands. Biogeosciences Discuss. 11, 5765-5809.

Enders, A., Hanley, K., Whitman, T., Joseph, S., Lehmann, J., 2012.Characterization of biochars to evaluate recalcitrance and agronomic performance. Bioresour. Technol.114, $644-653$. 
1 Ernst, G., Müller, A., Göhler, H., Emmerling, C., 2008. C and N turnover of fermented residues from biogas plants in soil in the presence of three different earthworm species (Lumbricus terrestris, Aporrectodea longa, Aporrectodea caliginosa). Soil Biol.

Biochem. 40, 1413-1420.

Eswaran, H., Reich, P., Beinroth, F., 1997. Global distribution of soils with acidity. In: Plant-Soil Interactions at Low pH. Moniz, A.C. et al. (eds.). Brazilian Soil Science Society.159-164.

Executive summary, Power sector, January-2016, Central Electricity Authority, Govt. of India, Ministry of Power. http://www.cea.nic.in/reports/monthly/executivesummary/2016/exe_summary-01.pdf FAO statistical yearbook, 2013.World food and agriculture. Food and Agriculture Organization of the United Nations.

Fleming, R. 2006. Feasibility of Using Anaerobic Digestion and Composting to Recover Additional Value from Spent Mushroom Substrate. http://agrienvarchive.ca/res_papers/download/fleming_SMS_Final_Report.pdf Friedel, J.K., Bezler, A., Fischer, W.R., 1996. Nitrogen mineralization of liquefied, anaerobically fermented cattle manure in soil. Agribiol. Res. 49, 1-9. Fuchs, J.G., 2008. Effects of compost and digestate on environment and plant production - results of two research projects, Research Institute of Organic Agriculture FiBL, CHFrick; A. Berner, ORBIT, Wageningen, The Netherlands Galvez, A., Sinicco, T., Cayuela, M.L., Mingoranceb, M.D., Fornasier, F., Mondinia, C., 2012. Short term effects of bioenergy by-products on soil C and N dynamics, nutrient availability and biochemical properties. Agric. Ecosyst. Environ. 160, 3-14. 
1 Ganesh, P.S., Sanjeevi, R., Gajalakhmi, S., Ramasamy, E.V., Abbasi, S.A., 2008. Recovery of methane-rich gas from solid-feed anaerobic digestion of ipomoea (Ipomoea carnea). Bioresour. Technol. 99, 812-818.

García-Sanchez, M., Siles, J.A., Cajthaml, T., García-Romera, I., Tlustos, P., Szakova, J. 2015. Effect of digestate and fly ash applications on soil functional properties and microbial communities. Europ. J. Soil Biol. 71, 1-12.

Garfi, M., Gelman, P., Comas, J., Carrasco, W., Fermer, I., 2011. Agricultural reuse of the digestate from low- cost tubular digestates in rural Andean communities. Waste Manage. 31, 2584-2589.

Gell, K., van Groenigen, J.W., Cayuela, M.L., 2011. Residues of bioenergy production 
Hazarika, S., Barooah, M.J., Dutta, P.K., Rajkhowa, P., 2015. Enriched Biogas Slurry A Potential Source of Nutrients for Organic Farming. Akshay Urja. http://mnre.gov.in/filemanager/akshay-urja/september-october-2015/EN/26-29.pdf

Haraguchi, M, Gorniak, S.L., Ikeda, K, Minami, Y., Kato, A., Watson, A.A., Nash, R.J., Molyneux, R.J., Asano, N., 2003. Alkaloidal Components in the Poisonous Plant, Ipomoea carnea (Convolvulaceae). J. Agric. Food Chem. 51, 4995-5000.

Hendriks, A.T.W.M., Zeeman, G., 2009. Pretreatments to enhance the digestibility of lignocellulosic biomass. Bioresour. Technol. 100, 10-18.

Herrmann, A, Sieling K, Wienforth B, Taube F, Kage H., 2013. Short-term effects of biogas residue application on yield performance and $\mathrm{N}$ balance parameters of maize in different cropping systems. J. Agric. Sci. 151, 449-462.

Hueza I.M., Guerra J.L., Haraguchi, M., Naoki, A., Górniak, S.L., 2005. The role of alkaloids in Ipomoea carneatoxicosis: a study in rats. Exp. Toxicol. Pathol. 57, 53-58. Indian Fertilizer Scenario, 2014, Department of Fertilizer, Ministry of Chemicals and Fertilizers, Govt. of India.

http://fert.nic.in/sites/default/files/Indian\%20Fertilizer\%20SCENARIO-2014_0.pdf Islam, M., Hossain, N., Alamgir, M., Kibria, M.G., 2014. Comparative Effects of Biogas Plant Residues, Poultry Manure and Inorganic Fertilizer on Growth and Yield of Ladies Finger. IOSR J. Agric. Veterin. Sci. 7, 29-33.

Jacob, L.W., 1998. Nutrient management planning for co-utilization of organic byproducts. In: Beneficial Co-Utilization of Agricultural, Municipal and Industrial byProducts. Brown, S.L., Angle, J.S., Jacobs, L.W., (eds.), Springer science+Business media, B.V., ISBN: 978-94-010-6128-5.

James, A.K., Thring, R.W., Helle, S., Ghuman, H.S., 2012. Ash Management ReviewApplications of Biomass Bottom Ash. Energies. 5, 3856-3873. 
Johansen, A., Carter, M.S., Jensen, E.S., Hauggard-Nielsen, H., Ambus, P., 2013. Effects of digestate from anaerobically digested cattle slurry and plant materials on soil microbial community and emission of $\mathrm{CO}_{2}$ and $\mathrm{N}_{2} \mathrm{O}$. Appl. Ecol. 63, 36-44.

Jorgensen, K., Jensen, L.S., 2009. Comparison Chemical and biochemical variation in animal manure solids separated using different commercial separation technologies.

Bioresour. Technol. 100, 3088-3096.

Kalra M.S., Panwar, J.S., 1986. Anaerobic digestion of rice crop residues. Agricultural Wastes. 17:263-269.

Kocar, G., 2008. Anaerobic Digesters: From Waste to Energy Cropsas an Alternative Energy Source. Energy Sources Part A. 30, 660-669.

Koszel, M., Lorencowicz, E., 2015. Agricultural use of biogasdigestate as a replacement fertilizers. Agric. Agric. Sci. Procedia. 7, $119-124$.

Krishnasamy, K., Nair, J., Bell, R., 2014. Evaluation of anaerobic digestate as a substrate for vermicomposting. Int. J. Environ. Waste Manage. 14, 149-164.

Kumar, A., Mohanta, K., Kumar, D., parkash, O., 2012. Properties and Industrial Applications of Rice husk: A review. Inter. J. Emerg. Technol. Adv. Eng. 2, 86-90. Kupper, T., Burge, D., Bachmann, H.J., Gusewell, S., Mayer, J., 2014. Heavy metals in source-separated compost and digestates. Waste Manage. 34, 867-874.

Laird, D.A., Fleming, P., Davis, D.D., Horton, R., Wang, B., Karlen, D.L., 2010. Impact of biochar amendments on the quality of a typical Midwestern agricultural soil.

Geoderma. 158, 443-449.

Lansing, S., Martin, J., Botero, R., Nogueira da Silva, T., Dias da Silva, E., 2010.Wastewater transformations and fertilizer value when co-digesting differing ratios of swine manure and used cooking grease in low-cost digesters. Biomass Bioenergy. 34, $1711-1720$. 
1 Lehmann, J., Gaunt, J., Rondon, M., 2006. Bio-char Sequestration in Terrestrial

2 Ecosystems - A Review. Mitig. Adapt. Strategies Glob. Chang. 11, 403-427.

Li, J., Wei, L., Duan, Q., Hu, G., Zhang, G., 2014. Semi-continuous anaerobic codigestion of dairy manure with three crop residues for biogas production. Bioresour. Technol. 156, 307-313.

Lin, K.S., Wang, H.P., Lin, C.J., Juch, C.I., 1998. A process development for gasification of rice husk. Fuel Proces. Technol. 55, 185-192.

Lorenz, K., Lal, R., Preston, C.M., Nierop, K.G.J., 2007. Strengthening the soil organic carbon pool by increasing contributions from recalcitrant aliphatic bio(macro)molecules. Geoderma. 142: 1-10.

Loria, E.R., Sawyer, J.E., Backer, D.W., Lundwall, J.P., Lorimor, J.C. 2007. Use of anaerobically digested swine manure as a nitrogen source in corn production. Agron. J. 99, 1119-1129.

Makadi et al, 2012. Digestate new nutrient: Biogas, Edited by Sunil Kumar, ISBN 978953-51-0204-5. Publisher: InTech, DOI: 10.5772/1793.

Massaccesi, L., Sordi, A., Micale, C., Cucina, M., Zadra, C., Di Maria, F., Gigliotti, G., 2013. Chemical characterisation of percolate and digestate during the hybrid solid anaerobic digestion batch process, Process Biochem. 48, 1361-1367.

Meira M., da Silva, E.P., David, J.M., David, J.P., 2012. Review of the genus Ipomoea: traditional uses, chemistry and biological activities. Braz. J. Pharmacognosy. 22, 683-713. Møller, H.B., Sommer, S.G., Ahring, B.K., 2002. Separation efficiency and particle size distribution in relation to manure type and storage conditions. Bioresour. Technol. 85 , 189-196.

Moller, K., Müller, T., 2012. Effects of anaerobic digestion on digestate nutrient availability and crop growth: A review. Eng. Life Sci.12, 242-257. 
1 Mussoline W, Esposito G, Lens P, Spagni A, Giordano A., 2013. Enhanced methane production from rice straw co-digested with anaerobic sludge from pulp and paper mill treatment process. Bioresour. Technol. 148, 135-143.

Mussoline, Q., 2013. Enhancing the methane production from untreated rice straw using an anaerobic co-digestion approach with piggery wastewater and pulp and paper mill sludge to optimize energy conversion in farm-scale biogas plants. Earth Sciences. Universit’e Paris-Est; Universit'e de Cassino.

Nabel, M., Barbosa, D.B.P., Horsch, D., Jablonowski, N.D., 2014. Energy crop (Sida hermaphrodita) fertilization using digestate under marginal soil conditions: A doseresponse experiment. Energy Procedia. 59, $127-133$.

Nardin, F., Mancini, M., Unterhofer, T., Mazzetto, F., 2014. New solutions for digestate solid/liquid separation to apply on small alpine farm biogas plants, In: Proceedings of International Conference of Agricultural Engineering, Zurich.

Nguyen, H.N., Ha-Duong, M., 2014. Rice husk gasification for electricity generation in Cambodia in December 2014: Field Trip Report. https://halshs.archives-ouvertes.fr/hal01107615/document

Nkoa, 2014. Agricultural benefits and environmental risks of soil fertilization with anaerobic digestates: a review, Agron. Sustain. Dev. 34, 473-492.

Noone, G., 1990. The treatment of domestic waste. In Anerobic digestion: A waste treatment technology, Wheatley A., (ed.), Elsevier Applied Science Publ.

Odlare, M., Pell, M., Svensson, K., 2008. Changes in soil chemical and microbiological properties during 4 years of application of various organic residues. Waste Manage. 28, $1246-1253$. 
1 Owamah, H.I., Dahunsi, S.O., Oranusi, U.S., Alfa, M.I., 2014. Fertilizer and sanitary quality of digestate biofertilizer from the co-digestion of food waste and human excreta. Waste Manage. 34, 747-752.

Pastor, L., Marti, N., Bouzas, A., Seco, A., 2008. Sewage sludge management for phosphorus recovery as struvite in EBPR wastewater treatment plants. Bioresour. Technol. 99, 4817-4824.

Patowary, D., West, H., Clarke, M., Baruah, D.C.,2016. Biogas Production from Surplus Plant Biomass Feedstock: Some Highlights of Indo-UK R\&D Initiative. Procedia Environ. Sci. 35, $785-794$.

Raposo, F., Cegri, V.F., De La Rubia, M.A., Borja, R., Beline, F., et al., 2011.

Biochemical methane potential (BMP) of solid organic substrates: evaluation of anaerobic biodegradability using data from an international inters laboratory study. J. Chem. Technol. Biotechnol. 86, 1088-1098.

Riva, C., Orzi, V., Carozzi, M., Acuitis, G., Boccasile, S., Lonati, F., Tambone, G., Adani, D.F., 2016. Short-term experiments in using digestate products as substitutes for mineral (N) fertilizer: Agronomic performance, odours, and ammonia emission impacts. Sci Tot. Environ. 547, 206-214.

Rivard, C.J., Rodriguez, J.B., Nagle, N.J., Self, J.R., Kay, B.D., Soltanpour, P.N.,Nieves, R.A., 1995. Anaerobic digestion of municipal solid waste. Appl. Biochem. Biotechnol. $51,125-135$.

Rubaek, G.H., Henriksen, K., Petersen, J., Rasmussen, B., Sommer, S.G.,1996. Effects of application technique and anaerobic digestion on gaseous loss from animal slurry applied to ryegrass (Loliumperenne). J.Agric. Sci. 126, 481-492. 
Salminen, E., Rintala, J., Harkonen, J., Kuitunen, M., Hogmander, H., Oikari, A., 2001. Anaerobically digested poultry slaughterhouse wastes as fertiliser in agriculture. Bioresour. Technol. 78, 81-88.

Sapp, M., Harrison, M., Hany, U., Charlton, A., Thwaites, R., 2015. Comparing the effect of digestate and chemical fertiliser on soil bacteria. Appl. Soil Ecol. 86, 1-9. Saveyn, H., Eder, P., 2014. End-of-waste Criteria for Biodegradable Waste Subjected to Biological Treatment (Compost \&Digestate): Technical Proposals. JRC Scientific and Policy Reports. European Commission, Joint Research Centre, Institute for Prospective Technological Studies. EUR 26425 EN.

Schimming, T., Jenett-Siems, K., Mann, P., Tofern-Reblin, B., Milson, J., Johnson, R.W., Deroin, T., Austin, D.F., Eich, E., 2005. Calystegines as chemotaxonomic markers in the Convolvulaceae. Phytochem. 66, 469-480.

Sebola, M.R., Tesfagiorgis, H.B., Muzenda, E., 2015. Methane Production from Anaerobic Codigestion of Cow Dung, Chicken Manure, Pig Manure and Sewage Waste. In: Proceedings of the World Congress on Engineering, London, U.K Seigler, D.S., 1995. Pyrrolizidine, Quinolizidine, and Indolizidine Alkaloids. In: Plant secondary metabolism, Springer Science +Business media Publ. ISBN 978-1-4613-72288. doi: 10.1007/978-1-4615-4913-0_30 Selling, R., Håkansson, T., Björnsson, L., 2008. Two-stage anaerobic digestion enables heavy metal removal. Water Sci. Technol.57, 553-558. http://www.iimahd.ernet.in/assets/snippets/workingpaperpdf/9641902932011-04-01.pdf Sharpley, A., and Moyer, B., 2000. Phosphorus forms in manure and compost and their release during simulated rainfall. J. Environ. Qual. 29, 1462-1469. Shitophyta, L.M., Budiyono, Fuadi, A.M., 2015. Biogas production from rice straw by solid-state anaerobic digestion. In: Proceedings of AIP, Indonesia. 

sugarcanegrowing soils by organic amendments under subtropical climatic conditions of India. Biol. Fert. Soils. 44, 367-376. SPCR 120-Swedish regulation, - Certification rules for digestate from biowaste by the quality assurance system of Swedish Waste Management. http://www.avfallsverige.se/fileadmin/uploads/Rapporter/Biologisk/English_summary_of _SPCR_120.pdf Suresh, A., Choi, H.L., Oh, D.I., Moon, O.K., 2009. Prediction of the nutrients value and biochemical characteristics of swine slurry by measurement of EC - Electrical conductivity. Bioresour. Technol. 100, 4683-4689.

Taheripour, F., Hertel, T.W., Tyner, W.E., Beckman, J.F., Birur, D.K., 2010. Biofuels and their by-products: Global economic and environmental implications. Biomass Bioenergy. $34,278-289$.

Tambone, F., Genevini, P., D’Imporzano, G., Adani, F., 2009.Assessing amendment properties of digestate by studying the organic matter composition and the degree of biological stability during the anaerobic digestion of the organic fraction of MSW. Bioresour. Technol. 100, 3140-3142.

Tambone, F., Scaglia, B., D’Imporzano, G., Schievano, A., Orzi, V., Salati, S., Adani, F., 2010. Assessing amendment and fertilizing properties of digestates from anaerobic digestion through a comparative study with digested sludge and compost. Chemosphere. $81,577-583$.

Tampio, E., Salo, T., Rintala, J., 2016. Agronomic characteristics of five different urban waste digestates. J. Environ. Manage. 169. 293-302. 
1 Teglia, C., Tremier, A., Martel, J., 2011. Characterization of solid digestates: part 2, assessment of the quality and suitability for composting of six digested products. Waste Biomass Valor. 2, 113-126.

Teglia, C., Tremier, A., Martel, J.L., 2011. Characterization of Solid Digestates: Part 1, Review of Existing Indicators to Assess Solid Digestates Agricultural Use. Waste Biomass Valor. 2, 43-58.

Terhoeven-Urselmans, T., Scheller, E., Raubuch, M., Ludwig, B., Joergensen, R.G., 2009. $\mathrm{CO}_{2}$ evolution and $\mathrm{N}$ mineralization after biogas slurry application in the field and its yield effects on spring barley. Appl. Soil Ecol. 42, 297-302.

Tigini, V., Franchino, M., Bona, F., Varese, G.C., 2016. Is digestate safe? A study on its ecotoxicity and environmental risk on a pig manure. Sci. Total Environ. 551-552, 127 132.

Turker, M., Celen, I., 2007. Removal of ammonia as struvite from anaerobic digester effluents and recyling of magnesium and phosphate. Bioresour. Technol. 98, 1529-1534. United Nations, World Population prospects, The 2015 Revision. Key findings and advance tables, 2015. Department of Economic and Social Affairs Population Division. http://esa.un.org/unpd/wpp/publications/files/key_findings_wpp_2015.pdf Van Soest, P.J., Robertson, J.B., Lewis, B.A., 1991. Methods for dietary fiber, neutraldetergent fiber and non-starch polysaccharides in relation to animal nutrition. J. Dairy Sci.74, 3583-3597.

Vaneeckhaute, C., Meers, E.,Ghekiere, G., Accoe, F., Tack, F.M.G., 2013. Closing the nutrient cycle by using bio-digestion waste derivatives as synthetic fertilizer substitutes: A fieldexperiment. Biomass Bioenergy. 55, 175-189. 
$1 \quad$ Walkley, A., Black, I.A., 1934. An examination of Degtjareff method for determining soil organic matter and a proposed modification of the chromic acid titration method. Soil Sci. 37, 29-37.

Walsh, J.J., Jones, D.L., Edwards-Jones, G., Williams, A.P., 2012. Replacing inorganic fertilizer with anaerobic digestate may maintain agricultural productivity at less environmental cost. J. Plant Nutr. Soil Sci. 175, 840-845.

Wang, Michael.,Huo, Hong., Arora, Salil., 2011. Methods of dealing with co-products of biofuels in life-cycle analysis and consequent results within the U.S. context. Energy Policy. 39, 5726-5736.

Westphal, A., Kucke, M., Heuer, H., 2016. Soil amendment with digestate from bioenergy fermenters for mitigating damage to Beta vulgaris subspp. by Heterodera schachtii. Appl. Soil Ecol. 99, 129-136.

WRAP,2009.Anaerobic digestate, Partial Financial Impact Assessment of the introduction of a Quality Protocol for the production and use of anaerobic digestate, Waste Protocols Project.

WRAP, 2012. Quality Digestate-Using quality anaerobic digestate to benefit crop. http://www.wrap.org.uk/sites/files/wrap/Using\%20quality\%20digestate\%20to\%20benefit $\% 20$ crops.pdf

Yadav, A.K., 2010. Organic Agriculture, Concept, Scenario, Principals and Practices. Director National Centre of Organic Farming, Ghaziabad National Centre of Organic Farming Department of Agriculture and Cooperation, Ministry of Agriculture, Govt of India, Uttar Pradesh.

Yadav, A.K., 2012. Status of organic agriculture in India 2010-11. Organic Farming Newsletter 8, 10-14. 
http://ncof.dacnet.nic.in/Newsletters/Organic_Farming_Newsletter/Volume_8/OFNLJune 2012.pdf

Yang, Z., Han, L., Li, Q., Piao, X., 2006. Estimating nutrient contents of pig slurries rapidly by measurement of physical and chemical properties. J. Agric. Sci., 1-7 Ye, J., Li, D., Sun, Y., Wang, G., Yuan, Y., Zhen, F., Wang, Y., 2013. Improved biogas production from rice straw by co-digestion with kitchen waste and pig manure. Waste Manage. 33, 2653-2658.

Yoon, S.J., Son, Y.I., Kim, Y.K., Lee, J.G., 2012. Gasification and power generation characteristics of rice husk and rice husk pellet using a downdraft fixed-bed gasifier. Ren. Energy. 42, 163-167.

Zeshan, Visvanathan, C., 2014. Evaluation of anaerobic digestate for greenhouse gas emissions at various stages of its management. Inter. Biodeter. Biodeg. 95, 167-175. Zhang, A., Liu, Y., Pan, G., Hussain, Q., Li, L., Zheng, J., Zhang, X., 2012. Effect of biochar amendment on maize yield and green-house gas emissions from a soil organic carbon poor calcareous loamy soil from Central China Plain. Plant Soil. 351, 263-275 Zhang, R., Zhang, Z., 1999. Biogasification of rice straw with an anaerobic-phased solids digester system. Bioresour. Technol., 68, 235-245.

Zirkler, D., Peters, A., Kaupenjohann, M., 2014. Elemental composition of biogas residues: Variability and alteration during anaerobic digestion. Biomass Bioenergy. 67, 89-98.

Zhang, T., Liu, L., Song, Z., Ren, G., Feng, Y., Han, X., Yang, G., 2013. Biogas Production by Co-Digestion of Goat Manure with Three Crop Residues. PLoS One, 8(6), 66845. 


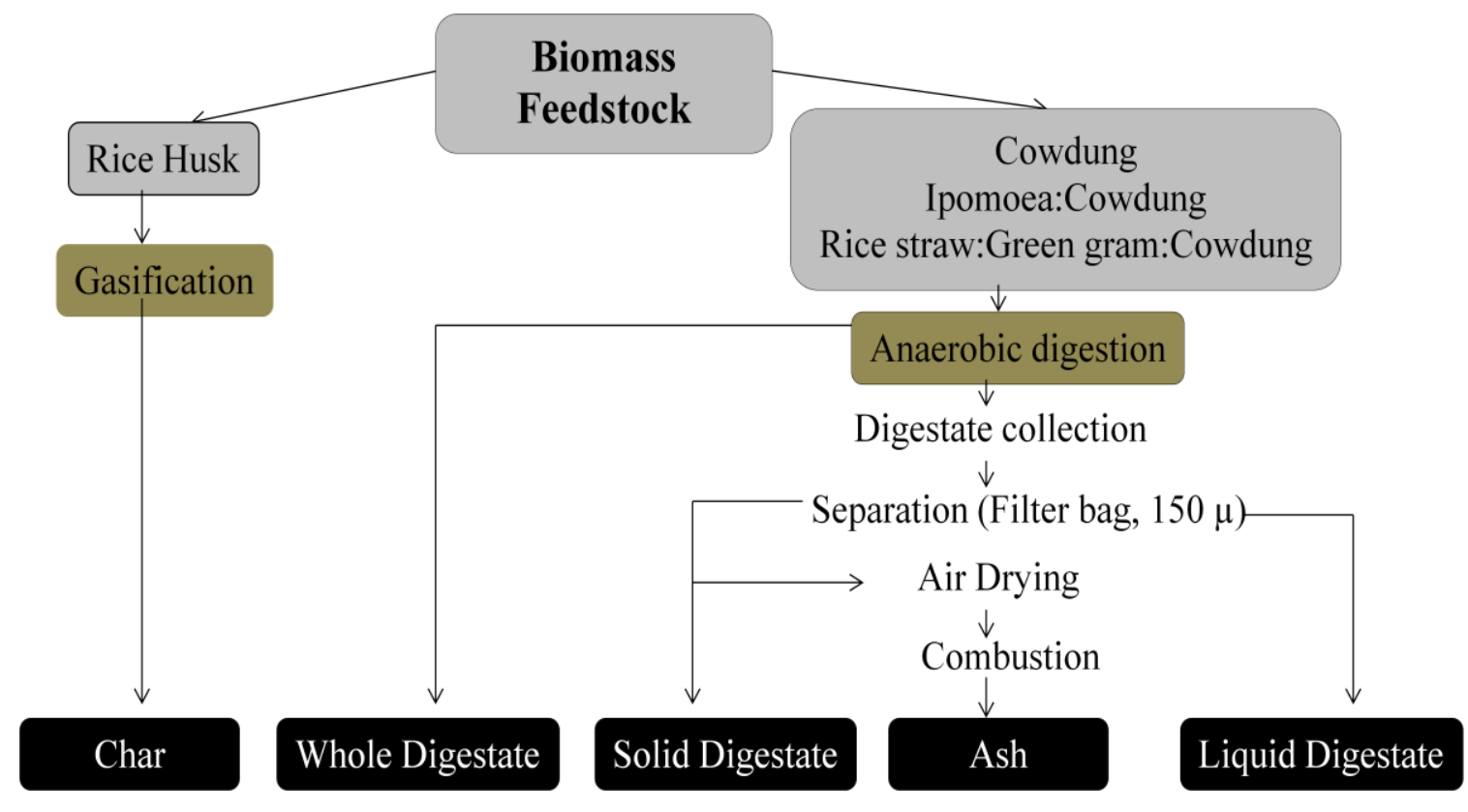

Fig.1. Schematic diagram of bioenergy by-product generation and processing 


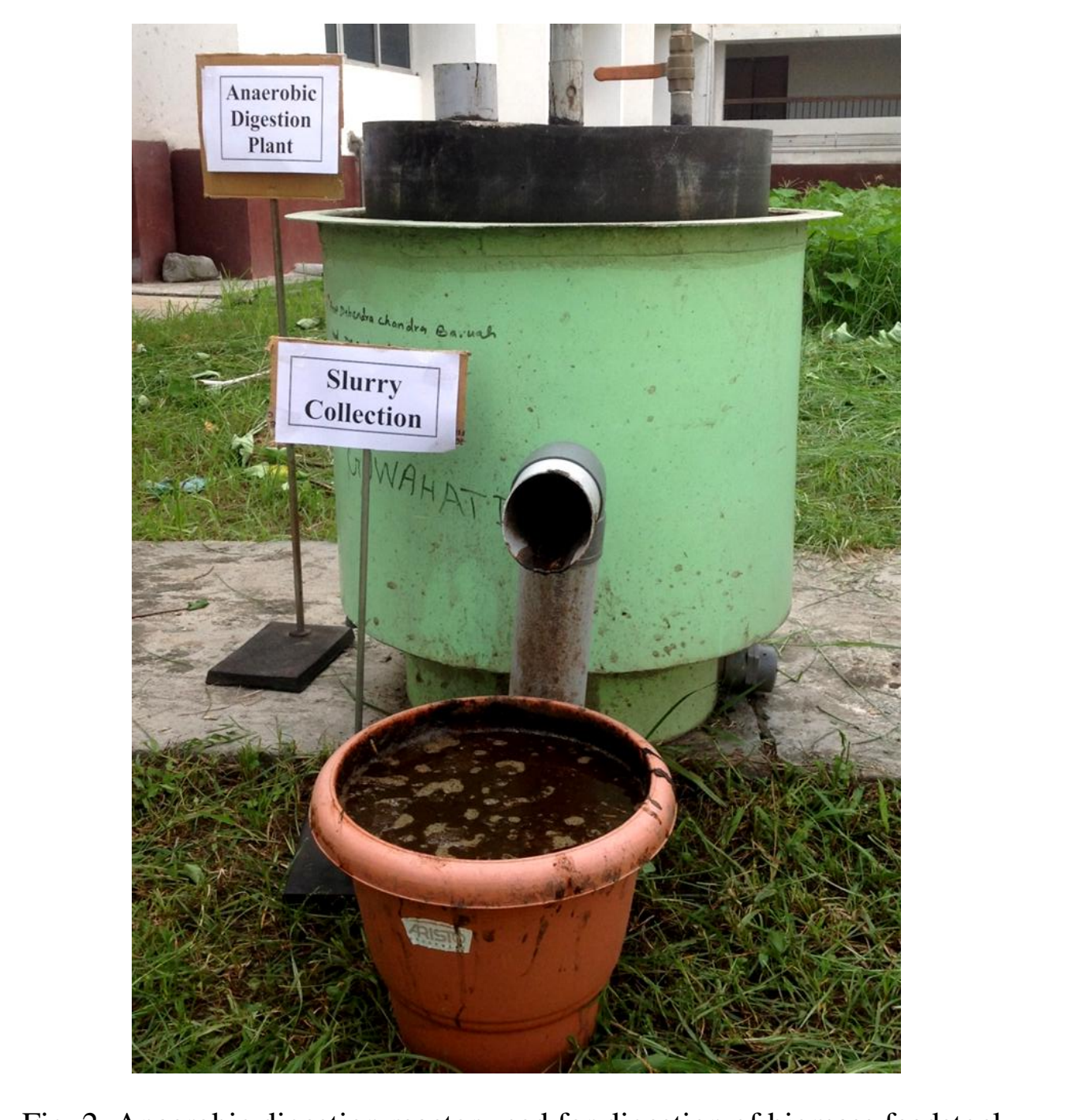

Fig. 2. Anaerobic digestion reactor used for digestion of biomass feedstock

\section{Figure 2_Digester}

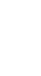

.

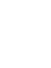

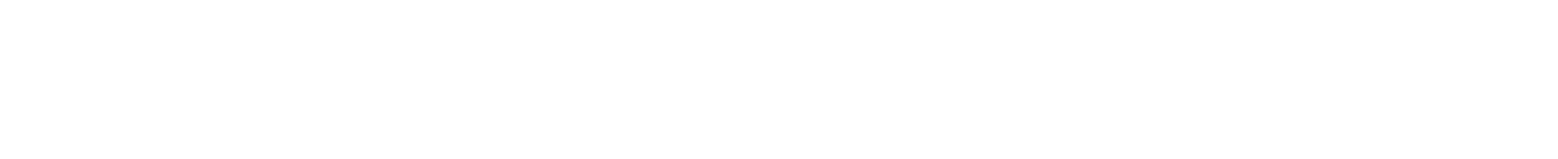

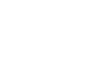

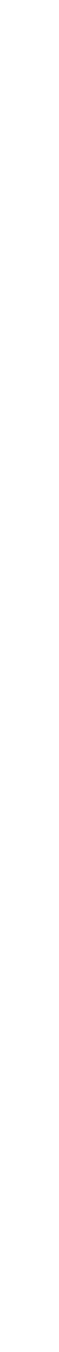


Figure 3_EC

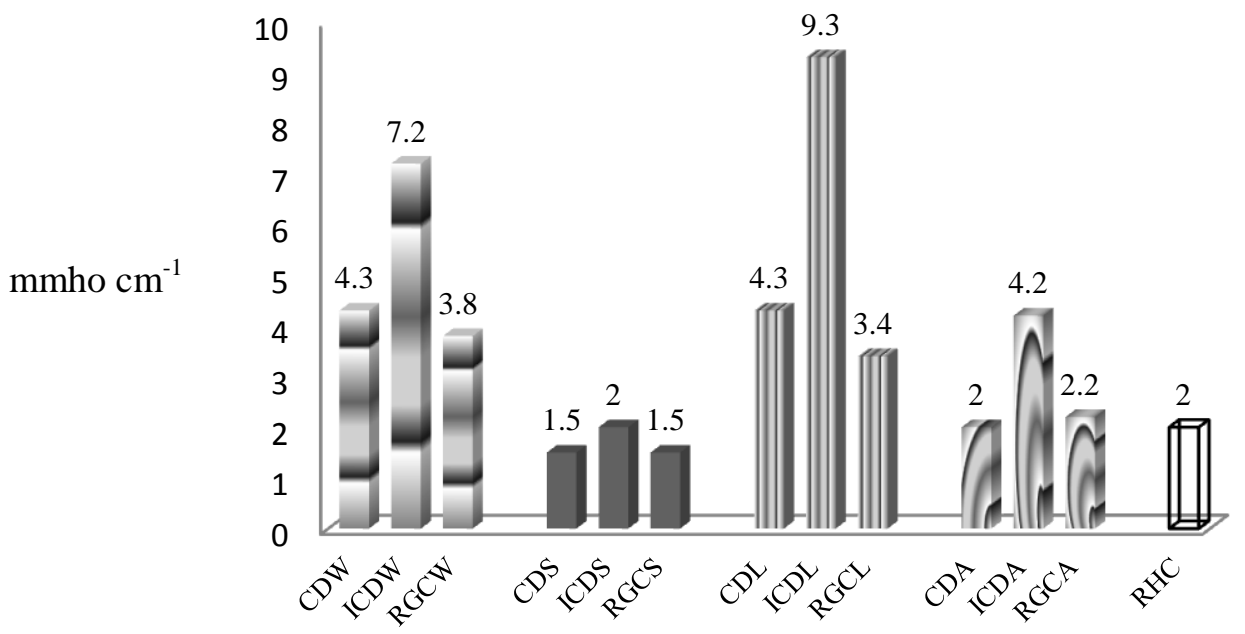

$\boldsymbol{C D}_{W}$ : Cowdung Whole, $\boldsymbol{C D}_{S}$ : Cowdung Solid, $\boldsymbol{C D}_{L}$ : Cowdung Liquid, $\boldsymbol{C D}_{A}$ : Cowdung Ash

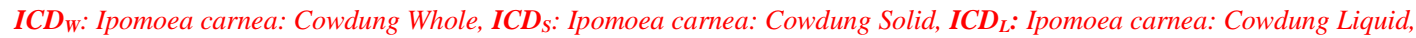

ICD $\boldsymbol{D}_{\text {A }}$ Ipomoea carnea:Cowdung Ash

$\boldsymbol{R G}_{W}$ : Rice straw:Green gram:Cowdung Whole, $\boldsymbol{R G C}_{S}$ : Rice straw:Green gram:Cowdung Solid, $\boldsymbol{R G C}_{\boldsymbol{L}}$ : Rice straw:Green gram:Cowdung Liquid, $\boldsymbol{R G}_{\mathrm{A}}$ : Rice straw:Green gram:Cowdung Ash

$\boldsymbol{R H}_{C}$ : Rice Husk Char

Fig. 3. Electrical conductivity of the BEBPs 


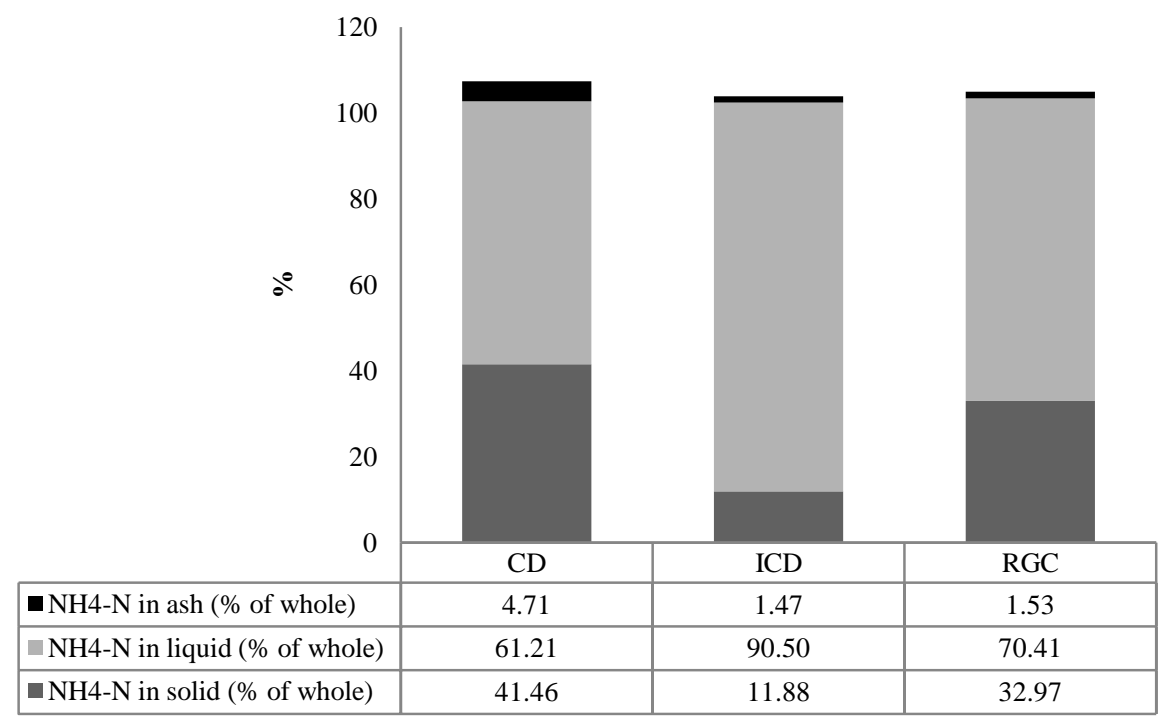

CD: Cowdung digestate

ICD: Ipomoea carnea :Cowdung Digestate

RGC: Rice straw: Green gram: Cowdung Digestate

Fig.4. $\mathrm{NH}_{4}-\mathrm{N}$ partitioning in solid/liquid/ash phase of digestates 


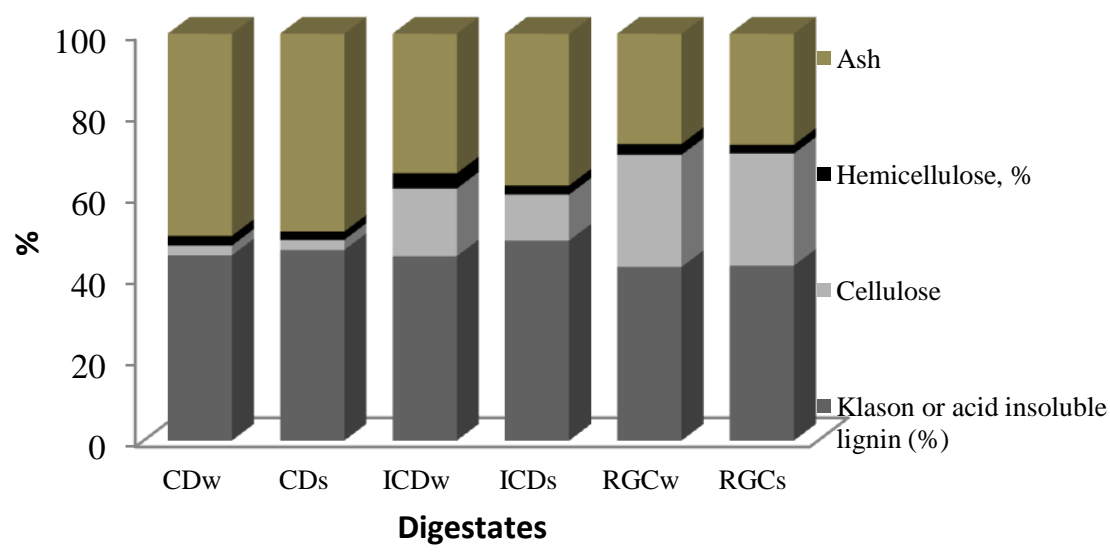

$\boldsymbol{C D}_{W}$ : Cowdung Whole, $\boldsymbol{C D}_{\mathrm{S}}$ : Cowdung Solid

ICD $D_{W}$ Ipomoea carnea: Cowdung Whole, ICDs: Ipomoea carnea: Cowdung Solid,

$\boldsymbol{R G}_{W}$ : Rice straw:Green gram:Cowdung Whole, $\boldsymbol{R G}_{\boldsymbol{S}}$ : Rice straw:Green gram:Cowdung Solid,

Fig. 5. Acid insoluble lignin (Klason lignin), Hemicellulose and Cellulose content of the BEBP whole and solid digestates (\% TS) 
Table 1

Energy, power and fertilizer scenario in India

\begin{tabular}{lr}
\hline \multicolumn{2}{c}{ Energy Requirement and Availability scenario in August, 2015* } \\
India
\end{tabular}


Table 2

Details of bioenergy by-products

\begin{tabular}{|c|c|c|c|}
\hline Energy system & Material & Phase & Abbreviation \\
\hline \multirow{12}{*}{ Anaerobic digestion } & \multirow[t]{4}{*}{ Cowdung } & Whole & $\mathrm{CD}_{\mathrm{W}}$ \\
\hline & & Solid & $\mathrm{CD}_{\mathrm{S}}$ \\
\hline & & Liquid & $\mathrm{CD}_{\mathrm{L}}$ \\
\hline & & Ash & $\mathrm{CD}_{\mathrm{A}}$ \\
\hline & \multirow{4}{*}{$\begin{array}{l}\text { Ipomoea Carnea leaves: Cowdung } \\
(60: 40)\end{array}$} & Whole & $\mathrm{ICD}_{\mathrm{W}}$ \\
\hline & & Solid & $\mathrm{ICD}_{\mathrm{S}}$ \\
\hline & & Liquid & $\mathrm{ICD}_{\mathrm{L}}$ \\
\hline & & Ash & $\mathrm{ICD}_{\mathrm{A}}$ \\
\hline & \multirow{4}{*}{$\begin{array}{l}\text { Rice straw: Green gram stover:Cowdung } \\
(30: 30: 40)\end{array}$} & Whole & $\mathrm{RGC}_{\mathrm{W}}$ \\
\hline & & Solid & $\mathrm{RGC}_{\mathrm{S}}$ \\
\hline & & Liquid & $\mathrm{RGC}_{\mathrm{L}}$ \\
\hline & & Ash & $\mathrm{RGC}_{\mathrm{A}}$ \\
\hline Gasification & Rice husk & Char & $\mathrm{RH}_{\mathrm{C}}$ \\
\hline
\end{tabular}




\section{Table 3}

Characteristics of individual feedstock

\begin{tabular}{lrrrrrrr}
\hline & $\begin{array}{r}\text { Moisture } \\
\text { Content, \% }\end{array}$ & $\begin{array}{r}\text { Ash (dry } \\
\text { basis), \% }\end{array}$ & $\begin{array}{r}\text { Volatile } \\
\text { Matter, \% }\end{array}$ & $\begin{array}{r}\text { Carbon, } \\
\mathbf{\%}\end{array}$ & $\begin{array}{r}\text { Hydrogen, } \\
\mathbf{\%}\end{array}$ & $\begin{array}{r}\text { Nitrogen, } \\
\mathbf{\%}\end{array}$ & C:N \\
\hline Cowdung & 64.76 & 24.57 & 66.5 & 39.4 & 5.18 & 1.84 & 21.41 \\
Ipomoea leaves & 47.06 & 8.07 & 72.19 & 43.44 & 5.54 & 1.43 & 30.38 \\
Green gram stover & 13.3 & 6.47 & 73.53 & 48.92 & 5.89 & 1.89 & 25.88 \\
Rice straw & 10 & 4.24 & 74.9 & 49.34 & 5.04 & 0.74 & 66.68 \\
Rice husk & 11.56 & 17.13 & 63.28 & 42.9 & 6.38 & 0.25 & 171.60 \\
\hline
\end{tabular}


Table 4

BEBP characterization method and protocol

\begin{tabular}{|c|c|c|c|}
\hline & \multirow{2}{*}{ Parameters } & \multicolumn{2}{|c|}{ Protocol/Method } \\
\hline & & Whole/Solid/Ash/Char & Liquid \\
\hline 1 & Total solid & By drying at $105^{\circ} \mathrm{C}$ for 24 hours & By drying at $105^{\circ} \mathrm{C}$ for 24 hours \\
\hline 2 & $\mathrm{pH}$ & $\begin{array}{l}\text { In homogenized water suspension of } \\
\text { BEBP in 1:10 (dry weight/volume) } \\
\text { ratio using pH meter }\end{array}$ & Measured directly using $\mathrm{pH}$ meter \\
\hline 3 & Electrical conductivity & $\begin{array}{l}\text { In homogenized water suspension of } \\
\text { BEBP in 1:10 (dry weight/volume) } \\
\text { ratio using Conductivity meter }\end{array}$ & $\begin{array}{l}\text { Measured directly using Conductivity } \\
\text { meter }\end{array}$ \\
\hline 4 & Total N & $\begin{array}{l}\text { Kjeldahl apparatus using } \mathrm{H}_{2} \mathrm{SO}_{4} \\
\text { digestion method }\end{array}$ & $\begin{array}{l}\text { Kjeldahl apparatus using } \mathrm{H}_{2} \mathrm{SO}_{4} \\
\text { digestion method }\end{array}$ \\
\hline 5 & Ammonia-N & $\begin{array}{l}\text { Distillation of } \mathrm{NaCl} \text { extracted } \\
\text { suspension of } \mathrm{BEBP} \text {, trapped in boric } \\
\text { acid and titrated with } 0.1 \mathrm{~N} \mathrm{HCl}\end{array}$ & $\begin{array}{l}\text { Distillation of } \mathrm{NaCl} \text { extracted } \\
\text { suspension of } \mathrm{BEBP} \text {, trapped in } \\
\text { boric acid and titrated with } 0.1 \mathrm{~N} \\
\mathrm{HCl}\end{array}$ \\
\hline 6 & Total organic carbon & $\begin{array}{l}\text { Loss on ignition at } 550^{\circ} \mathrm{C} \text { for } 10 \\
\text { hours }\end{array}$ & $\begin{array}{l}\text { Using } \mathrm{K}_{2} \mathrm{Cr}_{2} \mathrm{O}_{7} \text { oxidation method } \\
\text { (Walkley and Black, 1934) }\end{array}$ \\
\hline 7 & $\begin{array}{l}\mathrm{P}, \mathrm{K} \\
\mathrm{Cu}, \mathrm{Fe}, \mathrm{Mn}, \mathrm{Zn}, \mathrm{Mo}, \mathrm{Ni} \\
\mathrm{Al}, \mathrm{Cr}, \mathrm{Pb}, \mathrm{As}, \mathrm{Cd}, \mathrm{Se}\end{array}$ & Microwave digestion and ICP & Microwave digestion and ICP \\
\hline 8 & $\begin{array}{l}\text { Klason or Acid insoluble } \\
\text { Lignin/Cellulose/ } \\
\text { Hemicellulose }\end{array}$ & $\begin{array}{l}\text { Van Soest methodology for whole and } \\
\text { solid digestates (Van Soest et al., 1991) }\end{array}$ & Not determined \\
\hline
\end{tabular}


Table 5

$\mathrm{TS}, \mathrm{pH}, \mathrm{EC}$, Macronutrients (TN, $\left.\mathrm{NH}_{4}-\mathrm{N}, \mathrm{P}, \mathrm{K}\right)$, Total organic carbon and TOC:TN of BEBPs

\begin{tabular}{|c|c|c|c|c|c|c|c|c|}
\hline By-products & TS, $\mathrm{g} \mathrm{kg}^{-1} \mathbf{F M}$ & pH & $\begin{array}{r}\mathrm{TN}, \\
\mathrm{g} \mathrm{kg}^{-1} \mathbf{F M} \\
\end{array}$ & $\begin{array}{r}\mathrm{NH}_{4}-\mathrm{N}, \\
\mathrm{mg} \mathrm{kg}^{-1} \mathrm{FM} \\
\end{array}$ & $\begin{array}{r}\mathrm{K}, \\
\mathrm{g} \mathrm{kg}^{-1} \mathrm{FM}\end{array}$ & $\begin{array}{r}P, \\
\mathrm{~g} \mathrm{~kg}^{-1} \text { FM }\end{array}$ & $\begin{array}{r}\text { TOC, } \\
\% \text { DM }\end{array}$ & TOC:TN \\
\hline \multicolumn{9}{|c|}{ Anaerobic digestion by-product } \\
\hline $\mathrm{CD}_{\mathrm{W}}$ & 113.4 & $7.3 \pm 0.02^{\mathrm{a}}$ & $1.94 \pm 0.05^{\mathrm{ah}}$ & $123 \pm 12.3^{\mathrm{ac}}$ & $0.85 \pm 0.04^{\mathrm{a}}$ & $0.28 \pm 0.02^{\mathrm{ad}}$ & $27.42 \pm 1.2^{\mathrm{ad}}$ & 16.03 \\
\hline $\mathrm{ICD}_{\mathrm{W}}$ & 113.6 & $7.8 \pm 0.04^{\mathrm{b}}$ & $2.72 \pm 0.17^{\mathrm{ab}}$ & $790 \pm 50.0^{\mathrm{b}}$ & $1.53 \pm 0.08^{\mathrm{a}}$ & $0.37 \pm 0.01^{\mathrm{a}}$ & $40.16 \pm 3.7^{b}$ & 16.73 \\
\hline $\mathrm{RGC}_{\mathrm{W}}$ & 135.2 & $8.0 \pm 0.01^{\mathrm{c}}$ & $1.30 \pm 0.12^{\mathrm{ac}}$ & $116 \pm 8.5^{\mathrm{a}}$ & $1.06 \pm 0.08^{\mathrm{a}}$ & $0.19 \pm 0.00^{\mathrm{cd}}$ & $43.33 \pm 2.8^{c}$ & 40.99 \\
\hline Mean & 120.7 & 7.7 & 1.98 & 343 & 1.09 & 0.38 & 36.97 & 24.58 \\
\hline $\mathrm{CD}_{\mathrm{S}}$ & 299.2 & $8.1 \pm 0.01^{\mathrm{d}}$ & $4.44 \pm 0.37^{\mathrm{d}}$ & $165 \pm 7.3^{\mathrm{c}}$ & $1.53 \pm 0.03^{\mathrm{a}}$ & $0.65 \pm 0.03^{\mathrm{e}}$ & $25.82 \pm 1.5^{\mathrm{d}}$ & 17.95 \\
\hline $\mathrm{ICD}_{\mathrm{S}}$ & 225.3 & $8.0 \pm 0.01^{\mathrm{e}}$ & $4.71 \pm 0.73^{\mathrm{d}}$ & $399 \pm 28.6^{\mathrm{d}}$ & $1.60 \pm 0.01^{\mathrm{a}}$ & $0.87 \pm 0.00^{f}$ & $38.49 \pm 1.8^{\mathrm{b}}$ & 16.04 \\
\hline $\mathrm{RGC}_{\mathrm{S}}$ & 235.4 & $7.0 \pm 0.01^{f}$ & $2.60 \pm 0.31^{\mathrm{bh}}$ & $138 \pm 29.6^{\mathrm{ac}}$ & $1.34 \pm 0.06^{\mathrm{a}}$ & $0.52 \pm 0.01^{\mathrm{g}}$ & $44.54 \pm 2.4^{\mathrm{c}}$ & 40.14 \\
\hline Mean & 253.2 & 7.7 & 3.91 & 234 & 1.20 & 1.11 & 36.28 & 24.71 \\
\hline $\mathrm{CD}_{\mathrm{L}}$ & 31.0 & $8.5 \pm 0.01^{\mathrm{g}}$ & $0.85 \pm 0.08^{\mathrm{ce}}$ & $109 \pm 3.5^{\mathrm{a}}$ & $0.69 \pm 0.05^{\mathrm{a}}$ & $0.17 \pm 0.01^{\mathrm{cd}}$ & $0.55^{*} \pm 0.07^{\mathrm{e}}$ & 0.64 \\
\hline $\mathrm{ICD}_{\mathrm{L}}$ & 20.3 & $8.8 \pm 0.02^{h}$ & $2.18 \pm 0.30^{\mathrm{bh}}$ & $935 \pm 7.8^{\mathrm{e}}$ & $1.61 \pm 0.04^{\mathrm{a}}$ & $0.19 \pm 0.00^{\mathrm{cd}}$ & $2 * \pm 0.9^{\mathrm{e}}$ & 0.92 \\
\hline $\mathrm{RGC}_{\mathrm{L}}$ & 7.2 & $8.9 \pm 0.03^{\mathrm{i}}$ & $0.25 \pm 0.05^{\mathrm{e}}$ & $113 \pm 10.9^{a}$ & $0.81 \pm 0.08^{\mathrm{a}}$ & $0.06 \pm 0.01^{\mathrm{c}}$ & $0.18^{*} \pm 0.02^{\mathrm{e}}$ & 0.72 \\
\hline Mean & 19.5 & 8.7 & 1.09 & 381 & 0.87 & 0.11 & 0.91 & 0.78 \\
\hline $\mathrm{CD}_{\mathrm{A}}$ & 997.3 & $9.9 \pm 0.02^{j}$ & $7.54 \pm 0.41^{\mathrm{f}}$ & $164 \pm 45.7^{\mathrm{c}}$ & $9.68 \pm 0.61^{\mathrm{b}}$ & $8.42 \pm 0.16^{\mathrm{h}}$ & $6.92 \pm 0.9^{f}$ & 9.22 \\
\hline $\mathrm{ICD}_{\mathrm{A}}$ & 991.7 & $10.1 \pm 0.00^{\mathrm{k}}$ & $11.62 \pm 0.93^{\mathrm{g}}$ & $423 \pm 38.4^{\mathrm{f}}$ & $15.35 \pm 0.13^{c}$ & $5.00 \pm 0.18^{\mathrm{i}}$ & $11.85 \pm 1.6^{\mathrm{g}}$ & 11.17 \\
\hline $\mathrm{RGC}_{\mathrm{A}}$ & 999.2 & $9.7 \pm 0.03^{1}$ & $11.26 \pm 0.85^{\mathrm{g}}$ & $109 \pm 5.7^{\mathrm{a}}$ & $9.53 \pm 0.17^{\mathrm{d}}$ & $3.78 \pm 0.12^{\mathrm{j}}$ & $19.48 \pm 1.9^{\mathrm{h}}$ & 18.73 \\
\hline Mean & 996.0 & 9.9 & 10.14 & 260 & 11.52 & 5.73 & 12.75 & 13.04 \\
\hline \multicolumn{9}{|c|}{ Gasification by-product } \\
\hline $\mathrm{RH}_{\mathrm{C}}$ & 999.7 & $10.3 \pm 0.01^{\mathrm{m}}$ & $1.8 \pm 0.01^{\mathrm{a}}$ & $48 \pm 3.2^{\mathrm{g}}$ & $8.02 \pm 0.09^{\mathrm{e}}$ & $1.10 \pm 0.01^{j}$ & $28.65 \pm 2.9^{\mathrm{a}}$ & 143.27 \\
\hline
\end{tabular}

*Measured on fresh weight basis

FM: Fresh Matter

DM: Dry Matter, TS: Total Solid, TN: Total Nitrogen, $\mathrm{NH}_{4}-\mathrm{N}$ : Ammonia-Nitrogen, TOC: Total Organic Carbon

$\mathrm{CD}_{W}$ : Cowdung Whole, $\boldsymbol{C D}_{\mathrm{S}}$ : Cowdung Solid, $\mathrm{CD}_{\mathrm{L}}$ : Cowdung Liquid, $\mathbf{C D}_{\mathrm{A}}$ : Cowdung Ash

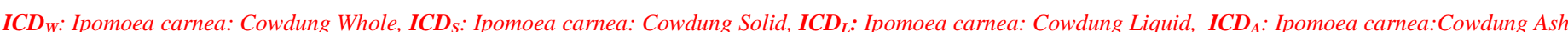

$\boldsymbol{R G C}_{W}$ : Rice straw:Green gram:Cowdung whole, $\boldsymbol{R G C}_{\mathrm{S}}$ : Rice straw:Green gram:Cowdung solid, $\boldsymbol{R G C}_{\mathrm{L}}$ : Rice straw:Green gram:Cowdung Liquid, $\boldsymbol{R}_{\mathbf{A}}$ : Rice straw:Green gram:Cowdung Ash $\boldsymbol{R H}_{\mathrm{C}}$ : Rice Husk Char 
Table 6

$\mathrm{N}: \mathrm{P}_{2} \mathrm{O}_{5}: \mathrm{K}_{2} \mathrm{O}$ value of the $\mathrm{BEBPs}$

\begin{tabular}{lr}
\hline BEBP & $\mathbf{N}_{\mathbf{2}} \mathbf{O}_{5}: \mathbf{K}_{\mathbf{2}} \mathbf{O}$ value \\
\hline Cowdung Whole & $3.03: 1: 1.59$ \\
Ipomoea carnea: Cowdung Whole & $3.23: 1: 2.19$ \\
Rice straw: Green gram: Cowdung Whole & $3.02: 1: 2.95$ \\
& \\
Cowdung Solid & $2.97: 1: 1.23$ \\
Ipomoea carnea: Cowdung Solid & $2.45: 1.03: 1$ \\
Rice straw: Green gram: Cowdung Solid & $2.18: 1: 1.35$ \\
& \\
Cowdung Liquid & $2.17: 1: 2.12$ \\
Ipomoea carnea: Cowdung Liquid & $5.06: 1: 1.48$ \\
Rice straw: Green gram: Cowdung Liquid & $1.92: 1: 6.23$ \\
& \\
Cowdung Ash & $1: 2.56: 1.54$ \\
Ipomoea carnea: Cowdung Ash & $1.01: 1 .: 1$ \\
Rice straw: Green gram: Cowdung Ash & $1.29: 1: 1.32$ \\
& \\
Rice Husk Char & $1: 1.4: 5.36$ \\
\hline
\end{tabular}


Table 7

Micronutrients (Ca, $\mathrm{Mg}, \mathrm{Fe}, \mathrm{S}, \mathrm{Cu}, \mathrm{Mn}, \mathrm{Zn}, \mathrm{Mo}, \mathrm{Ni}$ ) of BEBPs on fresh weight basis

\begin{tabular}{|c|c|c|c|c|c|c|c|c|c|}
\hline BEBPs & $\mathrm{Ca}, \mathrm{g} \mathrm{kg}^{-1}$ & $\mathrm{Mg}, \mathrm{g} \mathrm{kg}^{-1}$ & $\mathrm{~S}, \mathrm{~g} \mathrm{~kg}^{-1}$ & $\mathrm{Fe}, \mathrm{g} \mathrm{kg}^{-1}$ & $\mathrm{Cu}, \mathrm{mg} \mathrm{kg}^{-1}$ & Mn, mg kg $^{-1}$ & $\mathrm{Zn}, \mathrm{mg} \mathrm{kg}^{-1}$ & Mo, $\mathrm{mg} \mathrm{kg}^{-1}$ & $\mathrm{Ni}, \mathrm{mg} \mathrm{kg}^{-1}$ \\
\hline \multicolumn{10}{|c|}{ Anaerobic digestion by-product } \\
\hline $\begin{array}{l}\mathrm{CD}_{\mathrm{W}} \\
\mathrm{ICD}_{\mathrm{W}}\end{array}$ & $\begin{array}{l}0.24 \pm 0.02^{\mathrm{a}} \\
0.86 \pm 0.05^{\mathrm{b}}\end{array}$ & $\begin{array}{c}0.18 \pm 0.01^{\mathrm{ab}} \\
0.27 \pm 0.05^{\mathrm{b}}\end{array}$ & $\begin{array}{l}0.02 \pm 0.00^{\mathrm{a}} \\
0.19 \pm 0.02^{\mathrm{b}}\end{array}$ & $\begin{array}{l}0.11 \pm 0.01^{\mathrm{a}} \\
0.39 \pm 0.01^{\mathrm{a}}\end{array}$ & $\begin{array}{r}0.40 \pm 0.06^{\mathrm{a}} \\
1.89 \pm 0.21^{\mathrm{ab}}\end{array}$ & $\begin{array}{r}21.66 \pm 2.94^{\mathrm{a}} \\
64.44 \pm 11.26^{\mathrm{ab}}\end{array}$ & $\begin{array}{r}7.64 \pm 0.99^{\mathrm{ab}} \\
12.63 \pm 0.85^{\mathrm{ab}}\end{array}$ & $\begin{array}{r}0.03 \pm 0.00^{\mathrm{a}} \\
0.10 \pm 0.01^{\mathrm{ab}}\end{array}$ & $\begin{array}{l}0.15 \pm 0.02^{\mathrm{a}} \\
0.46 \pm 0.01^{\mathrm{a}}\end{array}$ \\
\hline $\mathrm{RGC}_{\mathrm{W}}$ & $0.58 \pm 0.00^{\mathrm{c}}$ & $0.24 \pm 0.01^{\mathrm{c}}$ & $0.10 \pm 0.02^{\mathrm{a}}$ & $0.25 \pm 0.03^{\mathrm{ba}}$ & $0.92 \pm 0.04^{\mathrm{ab}}$ & $53.72 \pm 3.76^{\mathrm{ab}}$ & $10.28 \pm 1.03^{\mathrm{ab}}$ & $0.07 \pm 0.00^{\mathrm{ab}}$ & $0.31 \pm 0.06^{\mathrm{a}}$ \\
\hline Mean & 0.56 & 0.23 & 0.10 & 0.25 & 1.07 & 46.61 & 10.18 & 0.07 & 0.31 \\
\hline $\mathrm{CD}_{\mathrm{S}}$ & $0.55 \pm 0.02^{\mathrm{d}}$ & $0.45 \pm 0.00^{\mathrm{d}}$ & $0.04 \pm 0.02^{\mathrm{a}}$ & $0.24 \pm 0.00^{\mathrm{ab}}$ & $0.98 \pm 0.07^{\mathrm{ab}}$ & $55.23 \pm 4.22^{\mathrm{ab}}$ & $16.90 \pm 2.19^{\mathrm{ab}}$ & $0.07 \pm 0.02^{\mathrm{ab}}$ & $0.38 \pm 0.08^{\mathrm{a}}$ \\
\hline $\mathrm{ICD}_{\mathrm{S}}$ & $2.01 \pm 0.00^{\mathrm{c}}$ & $0.58 \pm 0.00^{\mathrm{c}}$ & $0.59 \pm 0.03^{c}$ & $1.43 \pm 0.03^{\mathrm{c}}$ & $6.14 \pm 0.02^{\mathrm{b}}$ & $149.91 \pm 2.70^{\mathrm{b}}$ & $37.93 \pm 1.37^{\mathrm{c}}$ & $0.27 \pm 0.00^{\mathrm{ab}}$ & $1.57 \pm 0.03^{\mathrm{b}}$ \\
\hline $\mathrm{RGC}_{\mathrm{S}}$ & $1.68 \pm 0.05^{\mathrm{c}}$ & $0.54 \pm 0.01^{\mathrm{c}}$ & $0.28 \pm 0.02^{\mathrm{d}}$ & $0.78 \pm 0.16^{\mathrm{d}}$ & $3.08 \pm 0.13^{\mathrm{ab}}$ & $164.64 \pm 5.24^{\mathrm{b}}$ & $28.45 \pm 0.60^{\mathrm{bc}}$ & $0.19 \pm 0.01^{\mathrm{ab}}$ & $0.94 \pm 0.06^{\mathrm{ab}}$ \\
\hline Mean & 1.41 & 0.52 & 0.30 & 0.82 & 3.40 & 123.26 & 27.76 & 0.18 & 0.96 \\
\hline $\mathrm{CD}_{\mathrm{L}}$ & $0.15 \pm 0.00^{\mathrm{a}}$ & $0.14 \pm 0.00^{\mathrm{ab}}$ & BDL & $0.017 \pm 0.00^{\mathrm{a}}$ & $0.11 \pm 0.00^{\mathrm{a}}$ & $9.51 \pm 0.17^{\mathrm{a}}$ & $1.94 \pm 0.04^{\mathrm{a}}$ & $0.019 \pm 0.00^{\mathrm{a}}$ & $0.06 \pm 0.00^{\mathrm{a}}$ \\
\hline $\mathrm{ICD}_{\mathrm{L}}$ & $0.33 \pm 0.01^{\mathrm{a}}$ & $0.09 \pm 0.00^{\mathrm{a}}$ & $0.02 \pm 0.00^{\mathrm{a}}$ & $0.017 \pm 0.00^{\mathrm{a}}$ & $0.29 \pm 0.03^{\mathrm{a}}$ & $19.46 \pm 2.88^{\mathrm{a}}$ & $2.25 \pm 0.37^{\mathrm{a}}$ & $0.020 \pm 0.00^{\mathrm{a}}$ & $0.07 \pm 0.00^{\mathrm{a}}$ \\
\hline $\mathrm{RGC}_{\mathrm{L}}$ & $0.07 \pm 0.00^{\mathrm{a}}$ & $0.05 \pm 0.01^{\mathrm{ab}}$ & BDL & $0.001 \pm 0.00^{\mathrm{a}}$ & $0.02 \pm 0.01^{\mathrm{a}}$ & $2.28 \pm 0.99^{\mathrm{a}}$ & $0.57 \pm 0.13^{\mathrm{a}}$ & $0.014 \pm 0.00^{\mathrm{a}}$ & $0.01 \pm 0.00^{\mathrm{a}}$ \\
\hline Mean & 0.18 & 0.09 & 0.02 & 0.01 & 0.14 & 10.42 & 1.59 & 0.02 & 0.05 \\
\hline $\mathrm{CD}_{\mathrm{A}}$ & $11.94 \pm 0.06^{\mathrm{e}}$ & $7.33 \pm 0.21^{\mathrm{e}}$ & $0.94 \pm 0.05^{\mathrm{e}}$ & $13.09 \pm 0.18^{\mathrm{e}}$ & $27.98 \pm 4.66^{\mathrm{c}}$ & $1608 \pm 76.82^{\mathrm{c}}$ & $610 \pm 33.40^{\mathrm{d}}$ & $2.47 \pm 0.37^{\mathrm{c}}$ & $12.21 \pm 1.17^{\mathrm{c}}$ \\
\hline $\mathrm{ICD}_{\mathrm{A}}$ & $17.61 \pm 0.61^{\mathrm{f}}$ & $5.53 \pm 0.19^{f}$ & $2.30 \pm 0.12^{\mathrm{f}}$ & $11.54 \pm 0.47^{\mathrm{f}}$ & $47.92 \pm 6.99^{\mathrm{d}}$ & $1319 \pm 38.59^{\mathrm{d}}$ & $253 \pm 22.51^{\mathrm{e}}$ & $2.59 \pm 0.39^{\mathrm{c}}$ & $12.89 \pm 1.18^{\mathrm{c}}$ \\
\hline $\mathrm{RGC}_{\mathrm{A}}$ & $16.65 \pm 0.50^{\mathrm{g}}$ & $5.70 \pm 0.16^{\mathrm{g}}$ & $1.42 \pm 0.08^{\mathrm{g}}$ & $8.81 \pm 0.09^{\mathrm{g}}$ & $33.11 \pm 5.60^{\mathrm{e}}$ & $1836 \pm 78.35^{\mathrm{c}}$ & $360 \pm 7.63^{f}$ & $1.86 \pm 0.19^{\mathrm{d}}$ & $8.52 \pm 0.42^{\mathrm{d}}$ \\
\hline Mean & 15.40 & 6.19 & 1.55 & 11.14 & 36.33 & 1057 & 407 & 2.30 & 11.20 \\
\hline \multicolumn{10}{|c|}{ Gasification by-product } \\
\hline $\mathrm{RH}_{\mathrm{C}}$ & $1.36 \pm 0.05 \mathrm{~g}^{\mathrm{c}}$ & $0.77 \pm 0.02^{\mathrm{h}}$ & $0.56 \pm 0.00^{\mathrm{c}}$ & $0.26 \pm 0.01^{\mathrm{ab}}$ & $15.83 \pm 1.53^{\mathrm{f}}$ & $641 \pm 28.91^{\mathrm{e}}$ & $45 \pm 4.16^{\mathrm{c}}$ & $0.35 \pm 0.05^{\mathrm{ab}}$ & $3.60 \pm 0.33^{\mathrm{e}}$ \\
\hline
\end{tabular}

$C D_{W}$ : Cowdung Whole, $C D_{S}$ : Cowdung Solid, $C D_{L}$ : Cowdung Liquid, $C D_{A}$ : Cowdung Ash

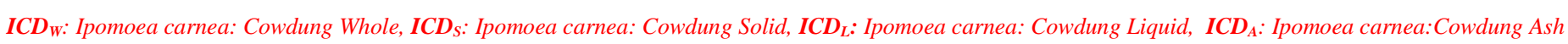

$\boldsymbol{R G C}_{W}$ : Rice straw:Green gram:Cowdung Whole, $\boldsymbol{R G C}_{\boldsymbol{S}}$ : Rice straw:Green gram:Cowdung Solid, $\boldsymbol{R G C}_{\mathbf{L}}$ : Rice straw:Green gram:Cowdung Liquid, $\boldsymbol{R G C}_{\boldsymbol{A}}$ : Rice straw:Green gram:Cowdung Ash

$\boldsymbol{R H}_{c}$ : Rice Husk Char 
Table 8

Heavy metals $(\mathrm{Cr}, \mathrm{Pb}, \mathrm{As}, \mathrm{Cd}, \mathrm{Se})$ and $\mathrm{Al}$ content of BEBPs on fresh weight basis

\begin{tabular}{|c|c|c|c|c|c|c|}
\hline BEBPs & $\mathrm{Al}, \mathrm{g} \mathrm{kg}^{-1}$ & $\mathrm{Cr}, \mathrm{mg} \mathrm{kg}^{-1}$ & $\mathrm{~Pb}, \mathrm{mg} \mathrm{kg}^{-1}$ & As, mg kg $^{-1}$ & $\mathrm{Cd}, \mathrm{mg} \mathrm{kg}^{-1}$ & Se, $\mathrm{mg} \mathrm{kg}^{-1}$ \\
\hline \multicolumn{7}{|c|}{ Anaerobic digestion by-products } \\
\hline $\begin{array}{l}\mathrm{CD}_{\mathrm{W}} \\
\mathrm{ICD}_{\mathrm{W}}\end{array}$ & $\begin{array}{c}0.06 \pm 0.002^{\mathrm{a}} \\
0.20 \pm 0.044^{\mathrm{ab}}\end{array}$ & $\begin{array}{l}0.11 \pm 0.013^{\mathrm{a}} \\
0.40 \pm 0.013^{\mathrm{a}}\end{array}$ & $\begin{array}{l}0.11 \pm 0.014^{\mathrm{a}} \\
0.34 \pm 0.017^{\mathrm{a}}\end{array}$ & $\begin{array}{l}0.04 \pm 0.002^{\mathrm{ab}} \\
0.12 \pm 0.013^{\mathrm{ab}}\end{array}$ & $\begin{array}{l}0.01 \pm 0.003^{\mathrm{a}} \\
0.03 \pm 0.002^{\mathrm{a}}\end{array}$ & $\begin{array}{r}0.002 \pm 0.00^{\mathrm{a}} \\
0.026 \pm 0.003^{\mathrm{ab}}\end{array}$ \\
\hline $\mathrm{RGC}_{\mathrm{W}}$ & $0.09 \pm 0.007^{\mathrm{a}}$ & $0.33 \pm 0.00^{\mathrm{a}}$ & $0.24 \pm 0.008^{\mathrm{a}}$ & $0.07 \pm 0.001^{\mathrm{ab}}$ & $0.04 \pm 0.009^{\mathrm{a}}$ & $0.020 \pm 0.003^{\mathrm{ab}}$ \\
\hline Mean & 0.12 & 0.28 & 0.23 & 0.08 & $\mathbf{0 . 0 3}$ & $\mathbf{0 . 0 2}$ \\
\hline $\mathrm{CD}_{\mathrm{S}}$ & $0.13 \pm 0.083^{\mathrm{ab}}$ & $0.28 \pm 0.00^{\mathrm{a}}$ & $0.26 \pm 0.045^{\mathrm{a}}$ & $0.09 \pm 0.010^{\mathrm{ab}}$ & $0.02 \pm 0.003^{\mathrm{a}}$ & $0.005 \pm 0.001^{\mathrm{bc}}$ \\
\hline $\mathrm{ICD}_{\mathrm{S}}$ & $0.70 \pm 0.018^{\mathrm{b}}$ & $1.50 \pm 0.037^{\mathrm{a}}$ & $1.16 \pm 0.033^{\mathrm{a}}$ & $0.36 \pm 0.004^{b}$ & $0.13 \pm 0.004^{\mathrm{a}}$ & $0.065 \pm 0.00^{\mathrm{cd}}$ \\
\hline $\mathrm{RGC}_{\mathrm{S}}$ & $0.33 \pm 0.028^{\mathrm{ab}}$ & $0.96 \pm 0.010^{\mathrm{a}}$ & $0.72 \pm 0.004^{\mathrm{a}}$ & $0.21 \pm 0.063^{\mathrm{ab}}$ & $0.09 \pm 0.005^{\mathrm{a}}$ & $0.034 \pm 0.002^{b}$ \\
\hline Mean & 0.39 & 0.91 & 0.71 & 0.22 & 0.08 & $\mathbf{0 . 0 3}$ \\
\hline $\mathrm{CD}_{\mathrm{L}}$ & $0.004 \pm 0.00^{\mathrm{a}}$ & $0.05 \pm 0.002^{\mathrm{a}}$ & $0.036 \pm 0.011^{\mathrm{a}}$ & $0.015 \pm 0.004^{\mathrm{ab}}$ & $0.008 \pm 0.001^{\mathrm{a}}$ & $0.001 \pm 0.001^{\mathrm{a}}$ \\
\hline $\mathrm{ICD}_{\mathrm{L}}$ & $0.006 \pm 0.001^{\mathrm{a}}$ & $0.02 \pm 0.004^{\mathrm{a}}$ & $0.048 \pm 0.002^{\mathrm{a}}$ & $0.027 \pm 0.003^{\mathrm{ab}}$ & $0.004 \pm 0.00^{\mathrm{a}}$ & $0.003 \pm 0.00^{\mathrm{a}}$ \\
\hline $\mathrm{RGC}_{\mathrm{L}}$ & $0.002 \pm 0.001^{\mathrm{a}}$ & $0.009 \pm 0.001^{\mathrm{a}}$ & $0.013 \pm 0.007^{\mathrm{a}}$ & $0.005 \pm 0.002^{\mathrm{a}}$ & $0.001 \pm 0.00^{\mathrm{a}}$ & BDL \\
\hline Mean & 0.004 & 0.026 & 0.032 & 0.016 & 0.004 & 0.002 \\
\hline $\mathrm{CD}_{\mathrm{A}}$ & $16.97 \pm 0.81^{\mathrm{c}}$ & $21.72 \pm 3.68^{\mathrm{b}}$ & $12.42 \pm 1.98^{\mathrm{b}}$ & $2.73 \pm 0.37^{\mathrm{c}}$ & $0.87 \pm 0.11^{\mathrm{b}}$ & $0.20 \pm 0.01^{\mathrm{e}}$ \\
\hline $\mathrm{ICD}_{\mathrm{A}}$ & $13.60 \pm 0.76^{\mathrm{d}}$ & $17.26 \pm 2.53^{\mathrm{c}}$ & $10.39 \pm 1.53^{\mathrm{c}}$ & $2.35 \pm 0.49^{\mathrm{d}}$ & $1.00 \pm 0.23^{\mathrm{c}}$ & $0.35 \pm 0.04^{\mathrm{f}}$ \\
\hline $\mathrm{RGC}_{\mathrm{A}}$ & $11.03 \pm 0.17^{\mathrm{e}}$ & $14.16 \pm 2.72^{\mathrm{d}}$ & $11.78 \pm 1.51^{\mathrm{c}}$ & $1.74 \pm 0.27^{\mathrm{c}}$ & $0.92 \pm 0.08^{\mathrm{b}}$ & $0.41 \pm 0.04^{\mathrm{g}}$ \\
\hline Mean & 13.86 & 17.71 & 11.53 & 2.27 & 0.93 & 0.32 \\
\hline \multicolumn{7}{|c|}{ Gasification by-product } \\
\hline $\mathrm{RH}_{\mathrm{C}}$ & $0.34 \pm 0.02^{\mathrm{ab}}$ & $0.34 \pm 0.08^{\mathrm{a}}$ & $1.07 \pm 0.10^{\mathrm{a}}$ & $0.40 \pm 0.12^{\mathrm{b}}$ & $0.013 \pm 0.00^{\mathrm{a}}$ & $0.08 \pm 0.01^{\mathrm{cd}}$ \\
\hline
\end{tabular}

$C D_{W}$ : Cowdung Whole, $C D_{S}$ : Cowdung Solid, $C D_{L}$ : Cowdung Liquid, $C D_{A}$ : Cowdung Ash

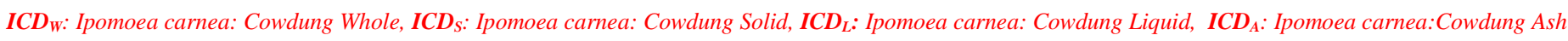

$\boldsymbol{R G C}_{W}$ : Rice straw:Green gram:Cowdung Whole, $\boldsymbol{R G C}_{\mathrm{S}}$ : Rice straw:Green gram:Cowdung Solid, $\boldsymbol{R G C}_{\mathbf{L}}$ : Rice straw:Green gram:Cowdung Liquid, $\boldsymbol{R G C C}_{\mathbf{A}}$ : Rice straw:Green gram:Cowdung Ash $\boldsymbol{R H}_{C}$ : Rice Husk Char 
Table_9_Comparative BEBP, others

Table 9

Comparison with similar by-products in literature and quality standard of organic fertilizer

\begin{tabular}{|c|c|c|c|c|c|c|c|c|c|c|c|c|c|c|c|c|c|c|}
\hline $\begin{array}{c}\text { Type of } \\
\text { digestate }\end{array}$ & pH & $\begin{array}{l}\text { TS, mg } \\
\mathrm{kg}^{-1}\end{array}$ & $\begin{array}{l}\text { TOC, \% } \\
\text { (stated } \\
\text { otherwise) }\end{array}$ & $\begin{array}{l}\text { EC, mS } \\
\text { cm }^{-1} \text { (stated } \\
\text { otherwise) }\end{array}$ & $\begin{array}{l}\mathrm{TN}, \mathrm{g} \mathrm{kg}^{-1} \\
\text { (stated } \\
\text { otherwise) }\end{array}$ & $\begin{array}{l}\text { P, } \mathbf{g ~ k g}^{-1} \\
\text { (stated } \\
\text { otherwise) }\end{array}$ & $\begin{array}{l}\mathbf{K}, \mathbf{g ~ k g}^{-} \\
{ }^{\text {1 (stated }} \\
\text { otherwise) }\end{array}$ & $\begin{array}{l}\mathrm{Ca} \\
\mathrm{g} \mathrm{kg}^{-1}\end{array}$ & $\begin{array}{l}\mathrm{Mg}, \\
\mathrm{g} \mathrm{kg}^{-1}\end{array}$ & $\begin{array}{l}\mathrm{Fe}, \\
\mathrm{g} \mathrm{kg}^{-1}\end{array}$ & $\begin{array}{l}\text { Mn, } \\
\mathrm{g} \mathrm{kg}^{-1}\end{array}$ & $\begin{array}{l}\text { Zn, } \\
\mathbf{g ~ k g}^{-1}\end{array}$ & $\begin{array}{l}\mathrm{Cu}, \\
\mathrm{mg} \mathrm{kg}^{-1}\end{array}$ & $\begin{array}{l}\mathrm{Cd}, \\
\mathrm{mg} \mathrm{kg}\end{array}$ & $\begin{array}{l}\mathrm{Cr} \\
\mathbf{m g} \\
\mathrm{kg}^{-1}\end{array}$ & $\begin{array}{l}\mathrm{Ni}, \\
\mathbf{m g} \\
\mathrm{kg}^{-1}\end{array}$ & $\begin{array}{l}\mathrm{Pb}, \\
\mathbf{m g} \\
\mathrm{kg}^{-1}\end{array}$ & References \\
\hline Whole digestates & $7.3-8.0$ & $113-135$ & $27-43$ & $3.8-7.2$ & $9.8-24$ & $0.79-3.27$ & $4.39-13.61$ & $\begin{array}{l}0.78- \\
7.07\end{array}$ & $\begin{array}{l}0.99- \\
2.27\end{array}$ & $\begin{array}{l}0.35- \\
3.83\end{array}$ & $\begin{array}{l}0.19- \\
0.57\end{array}$ & $\begin{array}{l}0.06- \\
0.11\end{array}$ & $\begin{array}{l}3.27- \\
15.72\end{array}$ & $\begin{array}{l}0.13- \\
0.16\end{array}$ & $\begin{array}{l}1.05- \\
3.63\end{array}$ & $\begin{array}{l}1.34- \\
4.01\end{array}$ & $\begin{array}{l}1.01- \\
3.04\end{array}$ & This study \\
\hline Solid digestates & $7.0-8.1$ & $225-300$ & $26-45$ & $1.5-2$ & $12.3-22.2$ & $2.12-3.76$ & $5.01-6.94$ & $\begin{array}{l}1.80- \\
7.35\end{array}$ & $\begin{array}{l}1.47- \\
2.54\end{array}$ & $\begin{array}{l}0.78- \\
7.35\end{array}$ & $\begin{array}{l}0.68- \\
1.60\end{array}$ & $\begin{array}{l}0.06- \\
0.16\end{array}$ & $\begin{array}{l}3.20- \\
26.60\end{array}$ & $\begin{array}{l}0.06- \\
0.56\end{array}$ & $\begin{array}{l}0.91- \\
6.48\end{array}$ & $\begin{array}{l}1.24- \\
6.81\end{array}$ & $\begin{array}{l}0.84- \\
5.03\end{array}$ & Do \\
\hline Liquid digestates* & $8.5-8.9$ & $7.2-31$ & $0.18-2$ & $3.4-9.3$ & $0.25-2.18$ & $0.06-0.19$ & $0.69-1.61$ & $\begin{array}{l}0.07- \\
0.33\end{array}$ & $\begin{array}{l}0.05- \\
0.14\end{array}$ & $\begin{array}{l}0.001- \\
0.017\end{array}$ & $\begin{array}{l}0.002- \\
0.019\end{array}$ & $<0.002$ & $\begin{array}{l}0.02- \\
0.29\end{array}$ & $\begin{array}{l}0.001- \\
0.008\end{array}$ & $\begin{array}{l}0.009- \\
0.05\end{array}$ & $\begin{array}{l}0.01- \\
0.07\end{array}$ & $\begin{array}{l}0.013- \\
0.048\end{array}$ & Do \\
\hline $\begin{array}{l}\text { Ash from solid } \\
\text { digestate }\end{array}$ & $9.7-10.1$ & 991-997 & $6.92-19.48$ & $2.0-4.2$ & $7.54-11.62$ & $5.78-8.42$ & $9.53-15.53$ & $\begin{array}{l}11.96- \\
17.64\end{array}$ & $\begin{array}{l}5.52- \\
7.55\end{array}$ & $\begin{array}{l}0.009- \\
0.013\end{array}$ & $\begin{array}{l}1.31- \\
1.83\end{array}$ & $\begin{array}{l}0.25- \\
0.58\end{array}$ & $\begin{array}{l}27.98- \\
42.72\end{array}$ & $\begin{array}{l}0.87- \\
1.00\end{array}$ & $\begin{array}{l}14.16- \\
21.12\end{array}$ & $\begin{array}{l}8.52- \\
12.89\end{array}$ & $\begin{array}{l}68.88- \\
84.11\end{array}$ & Do \\
\hline Municipal sludge & - & $131-185$ & $34-41.2$ & - & $50-73$ & $17.45-22.69$ & $2.10-7.00$ & 27.3 & 5.4 & 2.53 & - & 3906 & 6733 & 24.7 & 520 & 8.7 & 393 & $\begin{array}{l}\text { Tambone et al., } \\
2010\end{array}$ \\
\hline Maize & - & - & - & - & - & - & - & - & - & - & - & 34.3 & 28.5 & 0.05 & 16 & 5 & 1.3 & $\begin{array}{l}\text { Selling et al., } \\
2007\end{array}$ \\
\hline Human excreta & $6.5-7.6$ & $33-74$ & $20.1-39.84$ & - & $0.7-4$ & - & 0.002 & - & - & - & - & - & - & - & - & - & - & Gell et al., 2011 \\
\hline $\begin{array}{l}\text { Pig slurry+crop } \\
\text { residue }\end{array}$ & $8-8.2$ & & $27.6-30.3$ & & $138-205$ & $10-24$ & $103-105$ & $11-38$ & $5-15$ & $1.1-2.4$ & $\begin{array}{l}0.14- \\
0.54\end{array}$ & $\begin{array}{l}1.77- \\
4.01\end{array}$ & $206-681$ & - & - & - & - & $\begin{array}{l}\text { Zirkler et al., } \\
2014\end{array}$ \\
\hline Cattle +glycerine & $5.6-7.4$ & & & $\begin{array}{l}46.5- \\
58.7\end{array}$ & $32-49$ & $5-13$ & $22-47$ & $24-40$ & $5-7$ & $2.3-3$ & $\begin{array}{l}0.23- \\
0.35\end{array}$ & $\begin{array}{l}0.38- \\
0.47\end{array}$ & $172-278$ & - & - & - & - & $\begin{array}{l}\text { Zirkler et al., } \\
2014\end{array}$ \\
\hline Cowdung & $8.3-9.03$ & $19-61$ & $4.7-41.70$ & $\begin{array}{l}1.68- \\
3.05\end{array}$ & $3.8-32$ & & $0.014-1.9$ & 0.50 & 0.18 & 0.02 & 0.003 & 0.03 & 4 & - & - & - & - & $\begin{array}{l}\text { Gell et al., 2011, } \\
\text { Alburquerque et } \\
\text { al., } 2012\end{array}$ \\
\hline Pig manure & 8.5 & 102 & 37.90 & 19.77 & 44 & 22.3 & 0.009 & - & - & - & - & - & & - & - & - & - & $\begin{array}{l}\text { Galvez et al., } \\
2012\end{array}$ \\
\hline Guniea pig & 7.1 & 7 & $139.3 \mathrm{mg} \mathrm{l}^{-1}$ & $\begin{array}{l}6.88 \mathrm{uS} \\
\mathrm{cm}^{-1}\end{array}$ & $249.1 \mathrm{mg} \mathrm{l}^{-1}$ & $0.189 \mathrm{mg} \mathrm{l}^{-1}$ & $251 \mathrm{mg}^{-1}$ & - & - & - & - & - & - & - & - & - & - & Garfi et al., 2011 \\
\hline $\begin{array}{l}\text { Poultry } \\
\text { manure+sunflower } \\
\text { hull }\end{array}$ & - & - & - & - & - & - & - & - & - & - & - & 12.39 & 0.28 & 0.055 & 0.86 & 1.16 & 0.11 & $\begin{array}{l}\text { Demirel et al., } \\
2013\end{array}$ \\
\hline $\begin{array}{l}\text { Food and } \\
\text { vegetable waste }\end{array}$ & 8.42 & 120 & 18.8 & $\begin{array}{l}2.18 \\
\mathrm{dS}^{-1}\end{array}$ & 10.1 & 3.99 & 4.46 & 90.3 & 5.27 & 2.66 & 0.09 & 0.09 & 55.9 & & & & & $\begin{array}{l}\text { Krishnasamy et } \\
\text { al., } 2014\end{array}$ \\
\hline Vermi Compost & - & $850-750$ & 18.00 & - & & 3.49 & 6.64 & & - & - & - & - & - & 5 & 50 & 50 & 100 & $\begin{array}{l}\text { Indian Fertilizer } \\
\text { (control) order, } \\
1985\end{array}$ \\
\hline $\begin{array}{l}\text { Anaerobic } \\
\text { digestate }\end{array}$ & - & - & - & - & - & - & - & - & - & - & - & 0.4 & 200 & 1.5 & 100 & 50 & 200 & $\begin{array}{l}\text { BSI PAS } 110 \\
\text { specification, UK }\end{array}$ \\
\hline $\begin{array}{l}\text { Anaerobic } \\
\text { digestate }\end{array}$ & - & - & - & - & - & - & - & - & - & - & - & 0.8 & 600 & 1 & 100 & 50 & 100 & $\begin{array}{l}\text { SPCR 120- } \\
\text { Swedish } \\
\text { regulation }\end{array}$ \\
\hline $\begin{array}{l}\text { Anaerobic } \\
\text { digestate }\end{array}$ & - & - & - & - & - & - & - & - & - & - & - & 0.6 & 200 & 1.5 & 100 & 50 & 120 & $\begin{array}{l}\text { Saveyn and Eder, } \\
2014 \text { (EU } \\
\text { proposal) }\end{array}$ \\
\hline
\end{tabular}

Values are expressed on dry matter basis

*Measured on fresh weight basis 


\section{Table 10}

Significant correlations between various parameters of the BEBPs

\begin{tabular}{|c|c|c|c|c|c|c|c|c|c|c|c|c|c|c|c|c|c|c|c|c|}
\hline Parameter & TS & TOC & TN & $\mathbf{P}$ & $\mathbf{K}$ & $\mathbf{C a}$ & Mg & $\mathbf{S}$ & $\mathrm{Cu}$ & $\mathbf{F e}$ & Mn & $\mathbf{Z n}$ & Al & $\mathrm{Cr}$ & $\mathbf{P b}$ & As & Cd & Se & Mo & $\mathrm{Ni}$ \\
\hline TS & 1 & & & & & & & & & & & & & & & & & & & \\
\hline TOC & $0.798^{* *}$ & 1 & & & & & & & & & & & & & & & & & & \\
\hline TN & $0.757^{* *}$ & $0.465^{* *}$ & 1 & & & & & & & & & & & & & & & & & \\
\hline $\mathbf{P}$ & $0.785^{* *}$ & NS & $0.764 * *$ & 1 & & & & & & & & & & & & & & & & \\
\hline $\mathbf{K}$ & $-0.415^{* *}$ & NS & NS & NS & 1 & & & & & & & & & & & & & & & \\
\hline $\mathrm{Ca}$ & $0.811 * *$ & $0.449^{* *}$ & $0.954 * *$ & $0.823 * *$ & $-0.363^{*}$ & 1 & & & & & & & & & & & & & & \\
\hline Mg & $0.827 * *$ & $0.379 * *$ & $0.876^{* *}$ & $0.964 * *$ & $-0.358^{*}$ & $0.934 * *$ & 1 & & & & & & & & & & & & & \\
\hline $\mathbf{S}$ & $0.810^{* *}$ & $0.547^{* *}$ & $0.923^{* *}$ & $0.717^{* * *}$ & NS & $0.929^{* *}$ & $0.813^{* *}$ & 1 & & & & & & & & & & & & \\
\hline $\mathrm{Cu}$ & NS & NS & NS & NS & $0.841 * *$ & NS & NS & NS & 1 & & & & & & & & & & & \\
\hline $\mathrm{Fe}$ & NS & NS & NS & NS & $0.733^{* *}$ & NS & NS & NS & $0.896^{* *}$ & 1 & & & & & & & & & & \\
\hline Mn & NS & NS & NS & NS & $0.738^{* *}$ & NS & NS & NS & $0.888^{* *}$ & $0.986 * *$ & 1 & & & & & & & & & \\
\hline $\mathrm{Zn}$ & NS & NS & NS & NS & $0.634 * *$ & NS & NS & NS & $0.809^{* *}$ & $0.979 * *$ & $0.976^{* *}$ & 1 & & & & & & & & \\
\hline Al & NS & NS & & NS & $0.753^{* *}$ & NS & NS & NS & $0.931 * *$ & $0.989 * *$ & $0.977^{* *}$ & $0.963^{* *}$ & 1 & & & & & & & \\
\hline $\mathrm{Cr}$ & NS & NS & NS & NS & $0.629^{* *}$ & NS & NS & NS & $0.753^{* * *}$ & $0.411^{*}$ & $0.384 *$ & NS & $0.487^{* * *}$ & 1 & & & & & & \\
\hline $\mathbf{P b}$ & NS & NS & NS & NS & $0.651^{* *}$ & NS & $-0.316^{*}$ & NS & $0.770^{* *}$ & $0.434 *$ & $0.405^{*}$ & NS & $0.513 * *$ & $0.996 * *$ & 1 & & & & & \\
\hline As & $-0.337^{*}$ & NS & NS & $-0.320^{*}$ & $0.673^{* *}$ & NS & $-0.336^{*}$ & NS & $0.769^{* *}$ & $0.438 *$ & $0.408^{*}$ & NS & $0.516^{* *}$ & $0.980^{* *}$ & $0.986^{* *}$ & 1 & & & & \\
\hline Cd & $-0.323^{*}$ & NS & NS & $-0.324^{*}$ & $0.608^{* *}$ & NS & $-0.330^{*}$ & NS & $0.741^{* * *}$ & $0.394 *$ & $0.375^{*}$ & NS & $0.464 * *$ & $0.990 * *$ & $0.985^{* *}$ & $0.969^{* *}$ & 1 & & & \\
\hline Se & $-0.331 *$ & NS & NS & NS & $0.836^{* *}$ & NS & NS & NS & $0.965^{* *}$ & $0.777 * *$ & $0.754 * *$ & $0.664 * *$ & $0.834 * *$ & $0.865 * *$ & $0.883^{* *}$ & $0.888^{* *}$ & $0.608^{* *}$ & 1 & & \\
\hline Mo & $-0.415^{*}$ & NS & NS & NS & $0.865 * *$ & $-0.335^{*}$ & $-0.327 *$ & NS & $0.988^{* * *}$ & $0.859 * *$ & $0.868^{* *}$ & $0.761 * *$ & $0.890 * *$ & $0.770 * *$ & $0.782^{* *}$ & $0.778 * *$ & $0.768^{* *}$ & $0.865 * *$ & 1 & \\
\hline $\mathrm{Ni}$ & $-0.379 *$ & NS & NS & NS & $0.774 * *$ & NS & NS & NS & $0.951 * *$ & $0.984 * *$ & $0.978 * *$ & $0.948^{* * *}$ & $0.995 * *$ & $0.525 * *$ & $0.548^{* * *}$ & $0.550^{* *}$ & $0.511^{* *}$ & $0.774^{* *}$ & $0.920^{* *}$ & 1 \\
\hline
\end{tabular}

*Correlation is significant at $\mathrm{p}<0.05$ level, ${ }^{*}$ Correlation is significant at $\mathrm{p}<0.01$ level 


\section{Table 11}

Comparative assessment of different options of BEBPs application in a typical Indian crop rotation (Serial, Pulse, Oilseed)

\begin{tabular}{|c|c|c|c|c|c|c|c|}
\hline \multirow[t]{2}{*}{ BEBP } & \multicolumn{2}{|c|}{ BEBP requirements, tons/ha/annum** } & \multirow{2}{*}{$\begin{array}{l}\mathrm{K} \text { available from } \\
\text { processed BEBP } \\
\text { application, } \\
\mathrm{kg} / \mathrm{ha} / \text { annum }\end{array}$} & \multirow{2}{*}{$\begin{array}{l}\mathrm{P} \text { available from } \\
\text { processed BEBP } \\
\text { application, } \\
\mathrm{kg} / \mathrm{ha} / \text { annum }\end{array}$} & \multirow{2}{*}{$\begin{array}{r}\text { Additional K } \\
\text { requirement to fulfil } \\
\text { crop demand, } \\
\mathrm{kg} / \mathrm{ha} / \text { annum }\end{array}$} & \multirow{2}{*}{$\begin{array}{r}\text { Additional P } \\
\text { requirement to fulfil } \\
\text { crop demand, } \\
\mathrm{kg} / \mathrm{ha} / \text { annum }\end{array}$} & \multirow{2}{*}{$\begin{array}{r}\text { Biogas Plant Size } \\
\text { needed to generate } \\
\text { required whole } \\
\text { digestate, } \mathrm{m}^{3}\end{array}$} \\
\hline & $\begin{array}{r}\text { Estimated in terms } \\
\text { of mass of } \\
\text { processed BEBP }\end{array}$ & $\begin{array}{l}\text { Estimated in terms of } \\
\text { mass of parent BEBP } \\
\text { i.e. whole digestate }\end{array}$ & & & & & \\
\hline $\mathrm{ICD}_{\mathrm{W}}$ & 34.93 & 34.93 & 53.44 & 12.92 & 25.56 & 4.03 & 4.90 \\
\hline $\mathrm{CD}_{\mathrm{W}}$ & 48.97 & 48.97 & 41.62 & 13.71 & 26.35 & -7.78 & 5.37 \\
\hline $\mathrm{ICD}_{\mathrm{L}}$ & 43.58 & 56.99 & 70.59 & 8.33 & 25.39 & -31.81 & 6.25 \\
\hline $\mathrm{CD}_{\mathrm{S}}$ & 21.40 & 69.22 & 33.73 & 14.33 & 25.37 & 12.92 & 7.59 \\
\hline $\mathrm{RGC}_{\mathrm{W}}$ & 73.08 & 73.08 & 77.46 & 13.88 & 21.73 & 13.38 & 8.85 \\
\hline $\mathrm{ICD}_{\mathrm{S}}$ & 20.17 & 85.72 & 33.02 & 17.95 & 20.28 & -3.31 & 12.04 \\
\hline $\mathrm{RGC}_{\mathrm{S}}$ & 36.54 & 131.81 & 50.27 & 19.51 & 20.28 & -31.46 & 15.97 \\
\hline $\mathrm{CD}_{\mathrm{L}}$ & 111.76 & 161.79 & 77.21 & 19.02 & 31.00 & -24.51 & 17.73 \\
\hline $\mathrm{CD}_{\mathrm{A}}$ & 12.60 & 265.81 & 144.66 & 125.83 & 16.48 & -262.14 & 29.13 \\
\hline $\mathrm{ICD}_{\mathrm{A}}$ & 8.18 & 297.29 & 172.83 & 56.30 & -66.81 & -76.31 & 41.76 \\
\hline $\mathrm{RGC}_{\mathrm{L}}$ & 8.44 & 517.60 & 309.00 & 22.89 & -1.60 & -79.84 & 62.74 \\
\hline $\mathrm{RGC}_{\mathrm{A}}$ & 380.00 & 525.73 & 131.25 & 52.06 & 7.38 & -34.75 & 63.73 \\
\hline
\end{tabular}

** Estimated based on 100\% supplement of $N$ with different BEBP options

Recommended dose of $\mathrm{N}$ for Rice, Pulse and Oilseeds are 40, 15 and $40 \mathrm{~kg} \mathrm{~N} / \mathrm{ha}$, respectively

Recommended dose of $\mathrm{P}_{2} \mathrm{O}_{5}$ for Rice, Pulse and Oilseeds are 20, 35 and $35 \mathrm{~kg} \mathrm{P}_{2} \mathrm{O}_{5} /$ ha, respectively

Recommended dose of $\mathrm{K}_{2} \mathrm{O}$ for Rice, Pulse and Oilseeds are 20, 20 and $15 \mathrm{~kg} \mathrm{~K}_{2} \mathrm{O} /$ ha, respectively

CD whole digestates contain 31, 69 and $4.7 \%$ of solid, liquid and ash fraction, respectively

ICD whole digestates contain 24,76 and $2.7 \%$ of solid, liquid and ash fraction, respectively

RGC whole digestates contain 28,72 and $1.6 \%$ of solid, liquid and ash fraction, respectively

$25,19.5$ and $22.6 \mathrm{~kg}$ of whole digestates is generated daily from $1 \mathrm{~m}^{3}$ of biogas plant fed with $\mathrm{CD}$, ICD and RGC, respectively

(Estimated on the basis of mass balance of feedstock and gas production)

$\boldsymbol{C D}_{W}$ : Cowdung Whole, $\boldsymbol{C D}_{\mathrm{s}}$ : Cowdung Solid, $\boldsymbol{C D}_{L}$ : Cowdung Liquid, $\boldsymbol{C D}_{A}$ : Cowdung Ash

ICD $_{W}$ : Ipomoea carnea: Cowdung Whole, ICDs: Ipomoea carnea: Cowdung Solid, ICD $\boldsymbol{I C D}_{L}$ Ipomoea carnea: Cowdung Liquid, ICD $\boldsymbol{D}_{A}$ Ipomoea carnea:Cowdung Ash

$\boldsymbol{R G C}_{W}$ : Rice straw:Green gram:Cowdung whole, $\boldsymbol{R G C}_{S}$ : Rice straw:Green gram:Cowdung solid, $\boldsymbol{R G C}_{L}$ : Rice straw:Green gram:Cowdung Liquid, $\boldsymbol{R G C}_{A}$ : Rice straw:Green gram:Cowdung

$\boldsymbol{R H}_{C}:$ Rice Husk Char 